\title{
Effect of Soil Flexibility on Seismic Force Evaluation of RC Framed Buildings with Shear Wall: A Comparative Study of IS 1893 and EUROCODE8
}

\author{
B. R. Jayalekshmi and H. K. Chinmayi \\ Department of Civil Engineering, National Institute of Technology Karnataka, Surathkal 575025, India \\ Correspondence should be addressed to H. K. Chinmayi; chinmayi.moorthy@gmail.com
}

Received 29 November 2013; Revised 10 February 2014; Accepted 10 February 2014; Published 30 March 2014

Academic Editor: Chris G. Karayannis

Copyright (c) 2014 B. R. Jayalekshmi and H. K. Chinmayi. This is an open access article distributed under the Creative Commons Attribution License, which permits unrestricted use, distribution, and reproduction in any medium, provided the original work is properly cited.

\begin{abstract}
Conventional analyses of structures are generally carried out by assuming the base of structures to be fixed. However, the soil below foundation alters the earthquake loading and varies the lateral forces acting on structure. Therefore, it is unrealistic to analyse the structure by considering it to be fixed at base. Multistorey reinforced concrete framed buildings of different heights with and without shear wall supported on raft foundation incorporating the effect of soil flexibility are considered in present study to investigate the differences in spectral acceleration coefficient $\left(S_{a} / g\right)$, base shear, and storey shear obtained following the seismic provisions of Indian standard code and European code. Study shows that the value of base shear obtained for symmetric plan building is lowest in buildings with shear wall at all the four corners.
\end{abstract}

\section{Introduction}

Common practice of analysis and design of buildings is to assume the base of building to be fixed, whereas in reality supporting soil influences the structural response by permitting movement to some extent due to its natural ability to deform. The lessons learned from past earthquakes of neglecting the effect of soil showed the importance of considering soil-structure interaction in the seismic analysis of structures. The action in which the response of the soil influences the motion of the structure and the motion of the structure influences the response of the soil is known as soil-structure interaction (SSI). Applying soil-structure interaction effects enables the designer to evaluate the real displacements of the soil-structure system precisely under seismic motion. The seismic response of structures due to the effect of soil flexibility depends on both the soil property and structure property.

In seismic design of buildings, the consequences of soil flexibility are generally ignored. Mylonakis et al. [1] and Roy and Dutta $[2,3]$ showed the possible severities of neglecting the effects of the SSI in their studies. Similar study on implication of neglecting the SSI in ensuring the structural safety by conventional elastic and inelastic design procedure of moment-resisting building frames was shown by Tabatabaiefar et al. [4]. The effect of soil flexibility causing lengthening of lateral natural period in buildings due to lessening of lateral stiffness was reported by Bielak [5] and Stewart et al. [6, 7]. They reported that seismic responses of the buildings are altered by lengthening of lateral natural period, making it an important issue from the view-point of design considerations. Bhattacharya and Dutta [8] carried out studies on lowrise buildings having fundamental lateral period in short period region of the design response spectrum showing the significance of lengthening of natural period in seismic behaviour of structures. Impact of soil-structure interaction on base shear, interstorey shears, and moments of reinforced concrete buildings with underground storeys was studied by Saad et al. [9]. 3D finite element model to simulate the effects of soil-structure interaction on reinforced concrete moment resisting frames was employed by Tabatabaiefar and Massumi [10] indicating the significance of considering SSI in seismic 
design of RC-MRF buildings higher than three and seven storeys on soft soils. Raychowdhury [11] showed the virtues of accounting nonlinear soil-structure interaction analysis over conventional fixed-base and elastic-base models showing the significant reduction in force and displacement demands.

Finding the natural period of vibration of a reinforced concrete structure is a necessary procedure in earthquake design and assessment. Improved understanding on the global demands of structure under seismic action can be obtained from this sole characteristic natural period. Goel and Chopra [12] showed that seismic code formulas provide periods generally shorter than measured periods; hence, they developed an improved formula to provide better correlation with the frame buildings by regression analysis. Crowley and Pinho [13] derived analytical yield period-height relationships for bare frames using various methods to define the yield stiffness. Same author Crowley and Pinho [14] assessed the existing RC buildings taking into account the presence of infill panels to find the uncracked and yield period calculated using eigenvalue analysis for existing reinforced concrete buildings of varying height to be larger than simplified period height equation.

Karayannis et al. [15] addressed the application of adaptive analysis in inelastic analysis of reinforced concrete frames discussing the advantages of the methodology and highlighting the savings in computational time. Assessment of seismic performance of reinforced concrete frame structure with irregularities leading to soft first floor based on the capacity spectrum method (ATC-40) and coefficient method (FEMA 356) was carried out by Favvata et al. [16] showing the failure modes, capacity curves, interstorey drifts, ductility requirements, and infill behaviour.

Pong et al. [17] and Doğangün [18] carried out a comparative study on seismic provisions and so forth, base shear, and storey drift determination as per various international building codes. Comparative study on seismic design provisions of IBC 2000 and UBC 1997 codes in variation of base shear and quantity of steel in shear wall was reported by Ghosh [19]. Singh et al. [20] made a comparative study on various ductility classes and corresponding response reduction factors and reinforcement detailing provisions of seismic performance of a ductile RC frame building designed using four major codes, namely, ASCE7 (United States), EN1998-1 (Europe), NZS 1170.5 (New Zealand), and IS 1893 (India). Khose et al. [21] showed divergences existing in basic provisions, namely, minimum design base shear, ductility classification, and response reduction factor of four major national seismic building codes ASCE 7, Eurocode 8, NZS 1170.5, and IS 1893. A comparative study on seismic provisions of Iranian seismic code and International building code 2003 to determine the seismic forces by static analysis method stated in codes was carried by Imashi and Massumi [22]. Similar comparative evaluation of international, European and American, seismic design standard for analysis of conventional buildings was done by Santos et al. [23]. Yayong [24] compared the Chinese Code GB50011-2001 and the International Standard ISO3010:2001 (E), stressing the similarities and differences concerned in design requirements, seismic actions, and analytical approaches. Nahhas
[25] also compared the provisions of two building codes, the 1997 Uniform Building Code (UBC) and the 2000-2009 International Building Code (IBC), to evaluate the seismic forces yielded from a modal response spectrum analysis for ordinary residential buildings of standard occupancy by considering IBC as the benchmark code. Pong et al. [26] carried out a study concentrating on the similarities and differences between the seismic provisions of International building code 2003 (IBC 2003) and Mexico's manual of civil works for seismic design (MOC-93). Malekpour et al. [27] assessed performances of the structures designed as per Iranian (Standard No. 2800), European (EC8), and Japanese (BCJ) seismic codes with FEMA-356 and ATC-40 provisions and advantages and disadvantages of the codal provisions were discussed.

IS: 1893-2002 provisions in governing the method of analysis to be used for seismic design of buildings were analysed by Kaushik et al. [28]. Similarly Iervolino et al. [29] investigated the possibility of finding unscaled record sets fulfilling, the requirements of Eurocode 8 with respect to the seismic input for dynamic (time-history) analysis of spatial and plane structures.

A parametric study on determination of variation in lateral natural period, spectral acceleration coefficient $\left(S_{a} / g\right)$, base shear, and storey shear using Indian seismic code IS 1893(part1):2002 (IS) [30] and Eurocode 8 BS EN 1998-1: 2004 (EC8) [31] design spectrum for buildings assumed to be constructed over different soil sites and founded over different soil types is attempted in present study. The seismic response variation is also assessed by considering shear walls placed at core and all four corners of exterior frames of the building.

\section{Soil-Structure Interaction Analysis}

Soil-structure interaction analysis is carried out on multistorey reinforced concrete framed buildings of $4,6,8,12$, and 16 storeys with and without shear wall resting on raft foundation. The buildings considered are ordinary moment resisting frames with the effect of infill being neglected. To study the effect of shear wall, shear walls of same size were placed at the core and all four sides in the exterior frames of building at corners. For incorporating the effect of soil flexibility, four soil types classified based on shear wave velocity are considered in the study. Free vibration analysis of three dimensional building models founded on varying soil types is studied to find the effect of soil flexibility and significance of position of shear wall on lateral forces and design base shear of buildings.

2.1. Structural Idealization. Multistorey reinforced concrete framed buildings of 4, 6, 8, 12, and 16 storeys with and without shear wall on raft foundation are considered in present analysis. Buildings constitute ordinary moment resisting frames of 3 bays of equal length in each direction and with effect of infill being neglected. These buildings are symmetric in plan. Shear walls of same size were symmetrically placed in both directions of the building in plan at the core and all four 


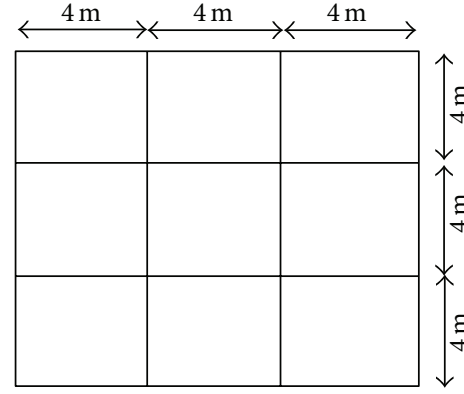

Bare frame

(a)

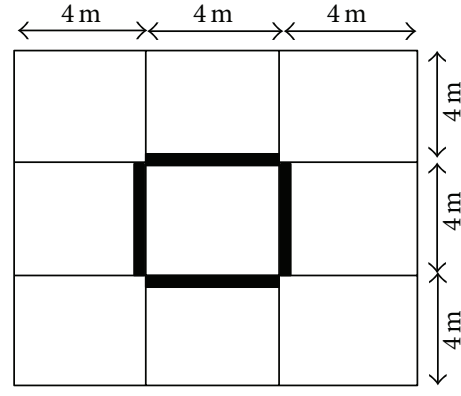

SW1

(b)

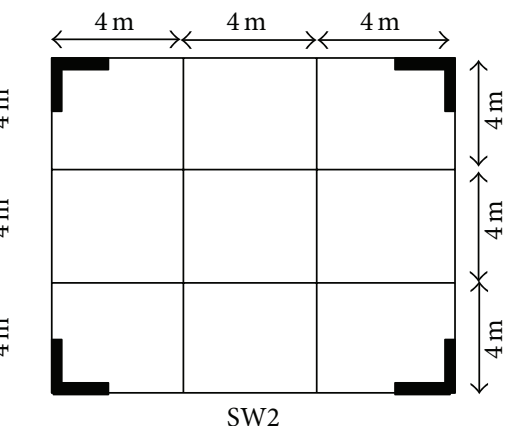

(c)

Figure 1: Plan of bare frame and frame with various locations of shear wall.

TABle 1: Dimensions of components of building.

\begin{tabular}{lccc}
\hline \multirow{2}{*}{$\begin{array}{c}c \\
\text { Storeys }\end{array}$} & \multicolumn{2}{c}{ Columns $(\mathrm{m})$} & Shear wall thickness $(\mathrm{m})$ \\
\hline 4 & $0.32 \times 0.32$ & $0.32 \times 0.32$ & 0.15 \\
6 & $0.35 \times 0.35$ & $0.35 \times 0.35$ & 0.15 \\
8 & $0.40 \times 0.40$ & $0.35 \times 0.35$ & 0.20 \\
12 & $0.50 \times 0.50$ & $0.40 \times 0.40$ & 0.20 \\
16 & $0.60 \times 0.60$ & $0.50 \times 0.50$ & 0.25 \\
\hline
\end{tabular}

corners of the exterior frames to study the effect of position of shear wall.

The building frames were idealised using 3D space frames with standard two-node beam element with three translational and three rotational degrees of freedom at each node. Roof slab, floor slabs at various storey levels, shear wall, and raft foundation slab were modelled with four-node plate elements with consideration of adequate thickness. Considering the building to be domestic or small office building the storey height was chosen as $3 \mathrm{~m}$ and length of each bay of all the building frames as $4 \mathrm{~m}$. Shear walls with thickness varying from 150 to $250 \mathrm{~mm}$ were considered depending on the building height.

Building components dimensions were reached on the basis of structural design following the respective Indian standard codes for design of reinforced concrete structures IS 456:2000 [32] and IS13920:1993 [33] for residential class buildings under normal gravity loads with a live load of $2.75 \mathrm{kN} / \mathrm{m}^{2}$. Dimensions of building components are as given in Table 1. Thickness of the raft foundation slab was taken as $0.3 \mathrm{~m}$. The thickness of floor slab at various storey levels and roof slab were taken as $0.15 \mathrm{~m}$ and beam dimensions as $0.23 \times 0.23 \mathrm{~m}$. The materials considered for design of structural elements were M20 concrete and Fe 415 steel.

The idealized forms of a typical 3 bay $\times 3$ bay frame having plan dimensions of $12 \mathrm{~m} \times 12 \mathrm{~m}$ with shear wall at the core and all four corners of the exterior frames in the building are represented schematically in Figure 1. Buildings with moment resisting frames alone without shear wall are denoted as "bare frame" (BF) and frames with shear wall at the core are denoted as "SW1" and at all four corners of the exterior frames as "SW2." Shear walls were placed such that the area of shear wall in both principal directions remains the same. Openings in shear walls were not considered assuming that additional strengthening and stiffening were provided around the openings.

2.2. Idealization of Soil. Soil is treated as a homogenous, isotropic, and elastic half space medium in examining the soil-foundation and structure interaction in the present study. The inputs for linear elastic analysis are density of soil, Young's modulus $\left(E_{s}\right)$, and Poisson's ratio $(\mu)$. Eight-node solid brick element having three degrees of freedom of translation in the $x, y$, and $z$ directions at each node is employed in modelling the soil medium underneath the raft. The width and thickness of the soil medium were taken as 1.5 times and 2 times the least width of the raft foundation beyond which it shows a negligible influence on the settlement and the contact pressure as reported by Maharaj et al. [34] and Thangaraj and Ilamparuthi [35]. The translations at the bottom boundary were restricted while the lateral vertical soil boundaries were modelled as nonreflecting boundaries. Fine finite element meshes were generated close to the raft with aspect ratio of 1.0 while the mesh away from the raft area was made coarser gradually. The primary aim of the present study is to see the effect of soil-structure interaction on buildings resting on different types of noncohesive soil, namely, soft, stiff, dense, and rock. FEMA 273 [36] and FEMA 356 [37] classify such soil profile types from hardest to softest as $\mathrm{Sb}, \mathrm{Sc}, \mathrm{Sd}$, and Se. The details of different soil parameters are tabulated in Table 2. Since classifications of soil sites are based on shear wave velocity or standard penetration test (SPT) values as per different seismic codes, they are mapped according to FEMA 356 (2000) classification for a uniform approach as shown in Table 3.

The finite element model of the idealized soil-foundationstructure system corresponding to a typical 16-storey frameshear wall building on raft foundation is shown in Figure 2.

\section{Methodology}

Correct assessment of fundamental periods of buildings is significant, since it is the chief parameter in the calculation 
TABLE 2: Details of soil parameters considered [FEMA 273 (1997) [36] and FEMA 356 (2000) [37]].

\begin{tabular}{lccccc}
\hline Soil profile type & Description & $\begin{array}{c}\text { Shear wave velocity } \\
\left(V_{s}\right)(\mathrm{m} / \mathrm{sec})\end{array}$ & $\begin{array}{c}\text { Poission's ratio } \\
\mu\end{array}$ & $\begin{array}{c}\text { Unit weight } \\
(\rho)\left(\mathrm{kN} / \mathrm{m}^{3}\right)\end{array}$ & $\begin{array}{c}\text { Young's modulus }\left(E_{s}\right) \\
\left(\mathrm{kN} / \mathrm{m}^{2}\right)\end{array}$ \\
\hline $\mathrm{Sb}$ & Rock & 1200 & 0.3 & 22 & $8.40 E+6$ \\
$\mathrm{Sc}$ & Dense soil & 600 & 0.3 & 20 & $1.91 E+6$ \\
$\mathrm{Sd}$ & Stiff soil & 300 & 0.35 & 18 & $4.46 E+5$ \\
$\mathrm{Se}$ & Soft soil & 150 & 0.4 & 16 & $1.03 E+5$ \\
\hline
\end{tabular}

TABLE 3: Mapping of soil sites of IS and EC8.

\begin{tabular}{lccc}
\hline \multirow{2}{*}{ Soil profile type } & Description & \multicolumn{2}{c}{ Equivalent site class } \\
& & IS & EC8 \\
\hline Sb & Rock & Type I & A \\
Sc & Dense soil & Type I & B \\
Sd & Stiff soil & Type II & C \\
Se & Soft soil & Type III & D \\
\hline
\end{tabular}

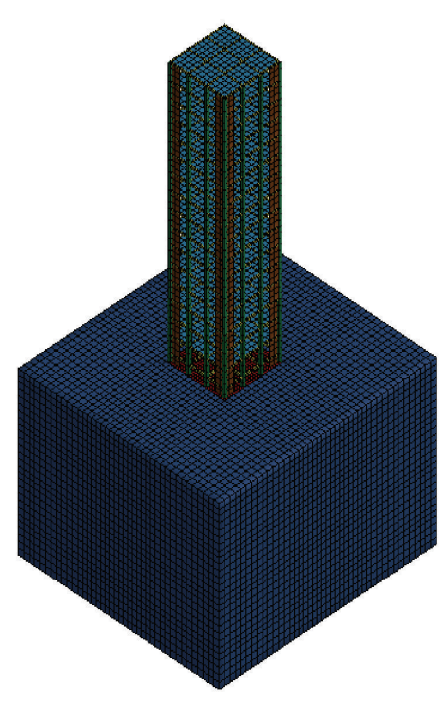

FIGURE 2: Idealized soil-foundation-structure model of 16-storey building.

of earthquake forces acting on a structure. Natural period of the structure is employed in estimating the lateral forces and design base shear based on the matching design response spectrum of code of practice. Design response spectrum presents the average smoothened plot of maximum acceleration as a function of time period of vibration for a specified damping ratio for earthquake excitations at the base of a single degree of freedom system equivalent to the structure. Design spectrum represented in IS and EC8 building codes for varying soil sites are shown in Figure 3.

The expressions for spectral acceleration coefficient for structures founded on various soil types suggested in IS and EC codes are described in the following sections.
3.1. Design Response Spectra and Design Base Shear as per IS1893 (part 1): 2002. The average spectral acceleration coefficients $\left(S_{a} / g\right)$ corresponding to natural period $T$ (sec) of structures represented as design response spectra in IS 1893 for various soil sites (Figure 3) are expressed as follows.

For rocky or hard soil site:

$$
\frac{S_{a}}{g}= \begin{cases}1+15 T ; & 0.00 \leq T \leq 0.10 \\ 2.50 ; & 0.10 \leq T \leq 0.40 \\ \frac{1.00}{T} ; & 0.40 \leq T \leq 4.00\end{cases}
$$

For medium soil site:

$$
\frac{S_{a}}{g}= \begin{cases}1+15 T ; & 0.00 \leq T \leq 0.10 \\ 2.50 ; & 0.10 \leq T \leq 0.55 \\ \frac{1.36}{T} ; & 0.55 \leq T \leq 4.00\end{cases}
$$

For soft soil site:

$$
\frac{S_{a}}{g}= \begin{cases}1+15 T ; & 0.00 \leq T \leq 0.10 \\ 2.50 ; & 0.10 \leq T \leq 0.67 \\ \frac{1.67}{T} ; & 0.67 \leq T \leq 4.00\end{cases}
$$

The design base shear which is the total horizontal force on the structure is calculated on the basis of structure mass and fundamental period of vibration and corresponding mode shape. The base shear of structure is calculated in accordance to the formula

$$
V_{B}=A_{h} W,
$$

where $A_{h}=$ design horizontal seismic coefficient based on the fundamental natural period $T$ in the considered direction of vibration and $W=$ seismic weight of the building.

The design horizontal seismic coefficient $A_{h}$ for a structure will be determined by

$$
A_{h}=\frac{Z I S_{a}}{2 R g},
$$

where $Z$ = zone factor, $I=$ importance factor, $R=$ response reduction factor, and $S_{a} / g=$ average response acceleration coefficient for rock and soil sites.

The seismic base shear is distributed throughout the structure in accordance with its mass and stiffness and is expressed as

$$
Q_{i}=V_{B} \frac{W_{i} h_{i}^{2}}{\sum_{j=1}^{n} h_{j}^{2}},
$$




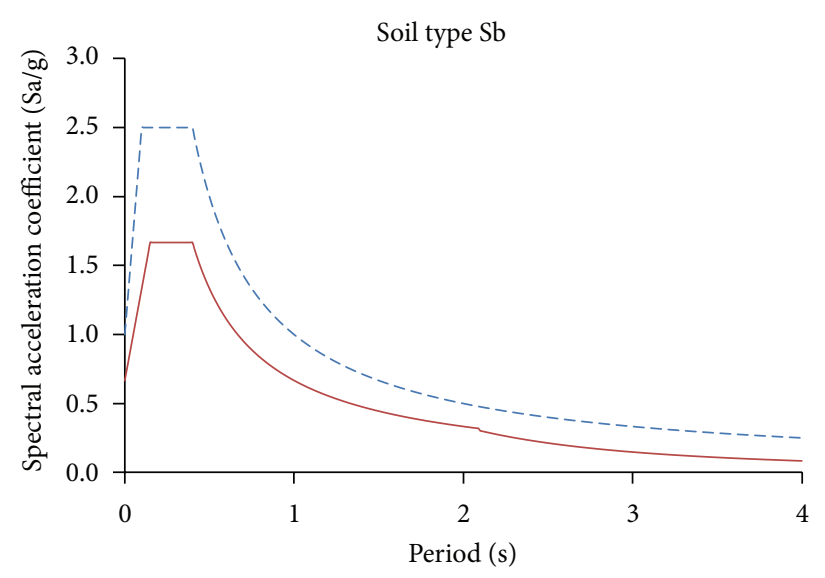

(a)

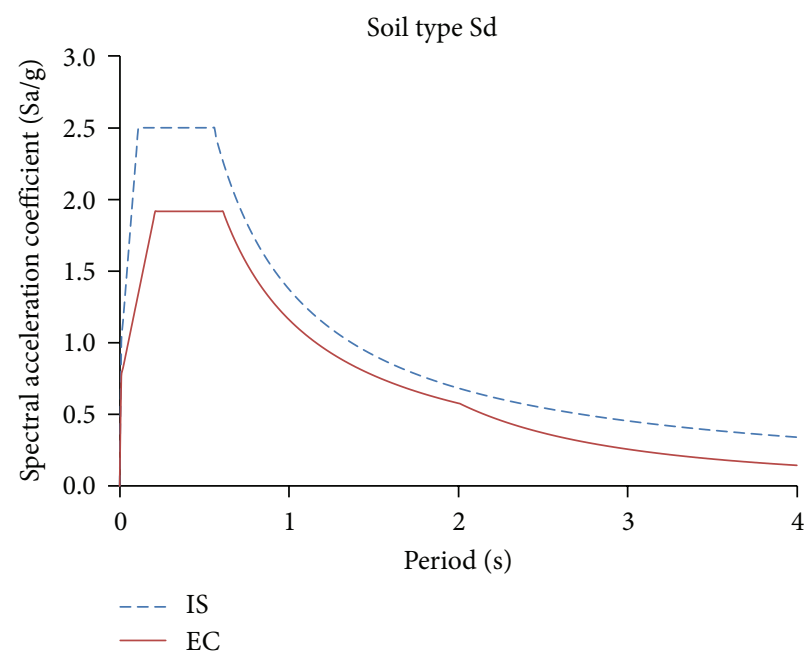

(c)

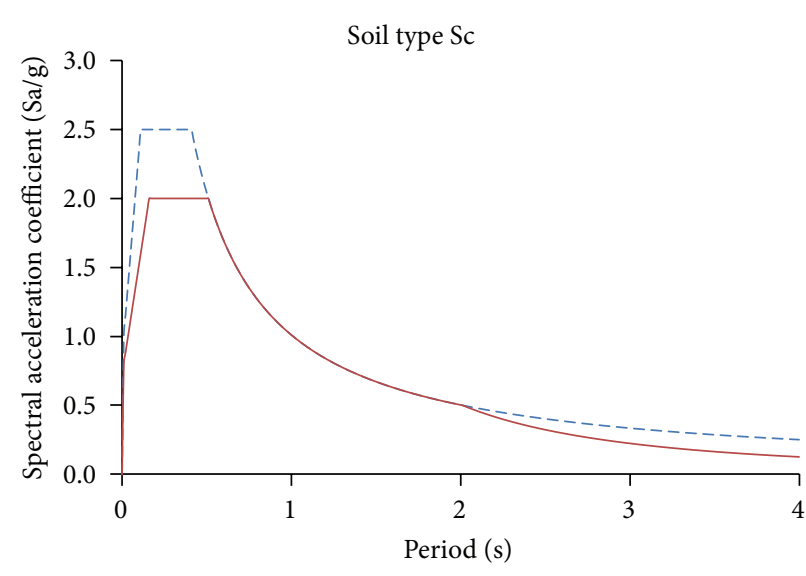

(b)

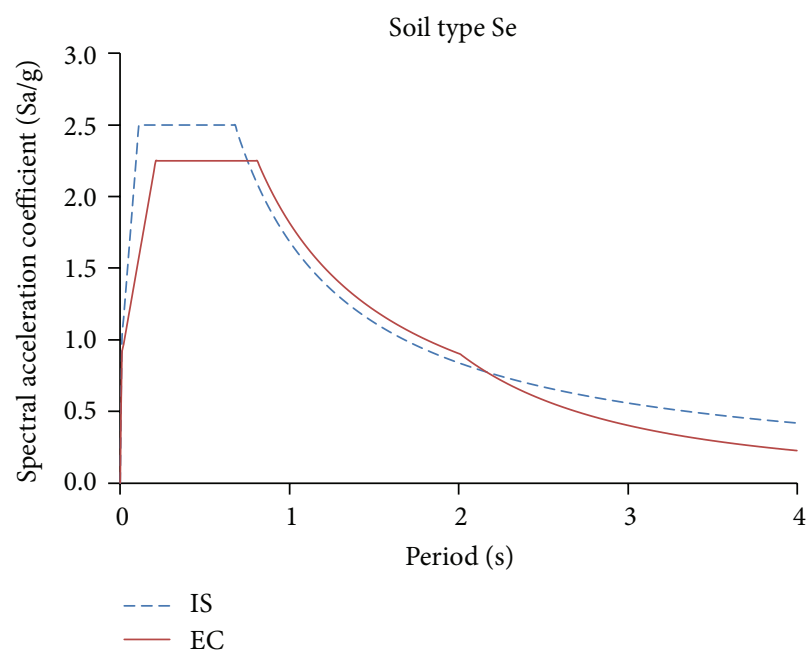

(d)

FIGURE 3: Design spectrum represented in IS and EC8 building codes for various soil sites.

where $Q_{i}=$ design lateral force at floor $i, W_{i}=$ seismic weight of floor $i, h_{i}=$ height of floor $i$ measured from base, and $n=$ number of storeys in the building (number of levels at which the masses are located).

3.2. Design Response Spectra and Seismic Base Shear as per Eurocode8: 2004. Design response spectra as per EC8 are as shown in Figure 3. The ordinates and shapes of response spectrum depend on the seismic hazard level and site class, respectively.

The design response spectra represented in Figure 3 are expressed as

$$
\begin{gathered}
0 \leq T \leq T_{B}: S_{d}(T)=a_{g} S\left[\frac{2}{3}+\frac{T}{T_{B}}\left(\frac{2.5}{q}-\frac{2}{3}\right)\right], \\
T_{B} \leq T \leq T_{C}: S_{d}(T)=a_{g} S \frac{2.5}{q}, \\
T_{C} \leq T \leq T_{D}: S_{d}(T)\left\{\begin{array}{l}
=a_{g} S \frac{2.5}{q}\left[\frac{T_{C}}{T}\right] \\
\geq \beta a_{g},
\end{array}\right.
\end{gathered}
$$

$$
T_{D} \leq T: S_{d}(T)\left\{\begin{array}{l}
=a_{g} S \frac{2.5}{q}\left[\frac{T_{C} T_{D}}{T^{2}}\right] \\
\geq \beta a_{g},
\end{array}\right.
$$

where $T$ is the vibration period of a linear SDOF: $T=$ $0.075 h^{0.75}$ for moment-resistant concrete frames and $T=$ $0.050 h^{0.75}$ for structures with concrete shear walls. $h$ is the height of the building in meters; $a_{g}$ is the design ground acceleration; $S$ is the soil factor; $T_{B}, T_{C}$ are the limiting periods of the spectrum's plateau (Table 4); $T_{D}$ is the lowest period of the constant displacement spectral portion (Table 4); $S_{d}(T)$ is the design spectrum; $q$ is the behaviour factor; $\beta$ is the lower bound factor for the horizontal design spectrum (the recommended value for $\beta$ is 0.2 ).

The behaviour factor " $q$ " is an approximation of the ratio of the seismic forces that the structure would experience if its response was completely elastic with $5 \%$ viscous damping to the seismic forces that may be used in the design, with a conventional elastic analysis model, still ensuring a satisfactory response of the structure. 
TABLE 4: Spectral shape controlling parameters according to EC8: 2004.

\begin{tabular}{lcccc}
\hline Siteclass & S-Factor & TB (s) & TC (s) & TD (s) \\
\hline A & 1.00 & 0.15 & 0.40 & 2.00 \\
B & 1.20 & 0.15 & 0.50 & 2.00 \\
C & 1.15 & 0.20 & 0.60 & 2.00 \\
D & 1.35 & 0.20 & 0.80 & 2.00 \\
E & 1.40 & 0.15 & 0.50 & 2.00 \\
\hline
\end{tabular}

The upper limit value of the behaviour factor, to account for energy dissipation capacity, should be greater than or equal to 1.5. In the present study value of behaviour factor is taken as 1.5. (Sec-5.2.2.2, BS EN 1998-1:2004)

The seismic base shear force $F_{b}$ for each horizontal direction in which building is analysed as per EC8: 2004 is given as

$$
F_{b}=S_{d}\left(T_{1}\right) m \lambda,
$$

where $S_{d}\left(T_{1}\right)$ is the ordinate of the design spectrum at period $T_{1} . T_{1}$ is the fundamental period of vibration of the building for lateral motion in the direction considered. $m$ is the total mass of the building, above the foundation or above the top of a rigid basement. $\lambda$ is the correction factor, which is equal to 0.85 if $T_{1} \leq 2 T_{c}$ and the building has more than two storeys or $\lambda=1.0$, otherwise.

When the fundamental mode shape is approximated by horizontal displacements increasing linearly along the height, the horizontal forces $F_{i}$ should be taken as

$$
F_{i}=F_{b} \frac{z_{i} m_{i}}{\sum_{j=1}^{n} z_{j} m_{j}}
$$

where $F_{i}$ is the horizontal force acting on storey $i, F_{b}$ is the seismic base shear in accordance with (8), $m_{i}, m_{j}$ are the storey masses computed, and $z_{i}, z_{j}$ are the heights of the masses $m_{i}$ and $m_{j}$ above the level of application of the seismic action (foundation or top of a rigid basement).

Simplified modal response spectrum analysis which takes into account mainly the fundamental mode of vibration in both main directions of the building was carried out on $3 \mathrm{D}$ space frames. This method is applicable to buildings with regularity in plan and elevation and the fundamental periods of vibration $\left(T=0.075 h^{0.75}\right.$ or $\left.T=0.050 h^{0.75}\right)$ less than or equal to $4 T_{c}$ or $2.0 \mathrm{sec}$ (as per EC8 clause no. 4.3.3.2.1). Based on the respective fundamental period and relevant design spectra which gives a static consideration of the seismic excitation, the seismic effects in the building were determined from the total inertia forces in the two main directions and their contribution along the height of the building. This method is often referred to as equivalent linear static analysis, where a totally dynamic phenomenon is dealt with.

The earthquake forces on the structure are determined using spectral acceleration corresponding to fundamental natural period $T$. The effect of soil-structure interaction and the position of shear walls in buildings constructed over different soil types are evaluated as variation in the estimated spectral acceleration and are compared as per seismic provisions of IS and EC8 seismic code in the present study. For this, multistorey reinforced concrete framed buildings of $4,6,8,12$, and 16 storeys with and without shear wall on raft foundation with $12 \mathrm{~m} \times 12 \mathrm{~m}$ plan dimensions were considered. These structures have regular configuration in plan and elevation. These structures were assumed to be constructed in zone IV with an importance factor of 1 . The response reduction factor $R$ of 3 was considered for moment resistant frames and 4.5 for ductile shear wall buildings as per IS code and equivalent parameters were considered as per EC8 code.

3D finite element model of soil-foundation-structure was generated and Eigen value analysis was carried out to determine the fundamental natural period " $T$ " of buildings with and without shear wall including soil flexibility. LS DYNA explicit dynamic analysis finite element software was used for this analysis. After finding the fundamental lateral periods of the building frames and shear wall buildings, with and without considering the effect of soil flexibility, the change in spectral acceleration coefficients $\left(S_{a} / g\right)$ corresponding to the natural period of structure was calculated from design response spectra of IS and EC8 code. The design base shear and lateral forces of the building were further obtained from the corresponding equations specified in building codes. In practice, the design base shear in buildings to be located at different site classes are obtained from $\left(S_{a} / g\right)$ values corresponding design spectrum based on the fundamental period of fixed base structure. These values corresponding to the fixed base structure to be built on different site classes are designated as "fixed." The value of $S_{a} / g$ computed from the base line for rocky strata of design response spectrum given in codes corresponding to the fundamental natural period of integrated soil-foundation-structure system is designated as "SSI." The results found were analysed and compared to assess the effect of location of shear wall, effect soil flexibility, effect soil type, and the seismic provisions in the codes.

\section{Results and Discussions}

Three dimensional finite element models of integrated soilraft foundation-RC shear wall buildings were considered for free vibration analysis to compute natural period of buildings accounting for the effect of soil-structure interaction. From the lateral natural periods obtained, the corresponding values of $S_{a} / g$ were computed as per the seismic provisions in IS and EC8 codes. The design base shear and lateral force distribution in the building were computed from the corresponding equations specified in building codes. The variations in base shear and storey shear due to the effect of soil flexibility and location of shear walls are analysed.

4.1. Lateral Natural Period. Fundamental natural period plays a significant role in the seismic response of a structure. The values of natural period obtained for the first four modes of bare frame and frame-shear wall buildings from the free vibration analysis of 3D finite element models are as tabulated in Table 5. Figure 4 shows the mode shapes of 1 st, $3 \mathrm{rd}$, and 4 th 
TABLE 5: Lateral natural period of building.

\begin{tabular}{|c|c|c|c|c|c|c|c|c|c|c|}
\hline \multirow{4}{*}{ Storeys } & \multirow{4}{*}{ Base Condition } & \multicolumn{9}{|c|}{ Lateral natural period of building (Sec) } \\
\hline & & \multirow{2}{*}{\multicolumn{3}{|c|}{$\begin{array}{l}\text { Bare frame } \\
\text { Mode }\end{array}$}} & \multirow{2}{*}{\multicolumn{3}{|c|}{$\begin{array}{l}\text { SW1 } \\
\text { Mode }\end{array}$}} & \multirow{2}{*}{\multicolumn{3}{|c|}{$\begin{array}{l}\text { SW2 } \\
\text { Mode }\end{array}$}} \\
\hline & & & & & & & & & & \\
\hline & & 1 & 3 & 4 & 1 & 3 & 4 & 1 & 3 & 4 \\
\hline \multirow{5}{*}{4} & Fixed & 0.85 & 0.71 & 0.26 & 0.18 & 0.16 & 0.06 & 0.35 & 0.21 & 0.08 \\
\hline & $\mathrm{Sb}$ & 1.00 & 0.75 & 0.29 & 0.19 & 0.17 & 0.06 & 0.36 & 0.21 & 0.08 \\
\hline & Sc & 1.00 & 0.75 & 0.29 & 0.22 & 0.17 & 0.06 & 0.38 & 0.22 & 0.09 \\
\hline & Sd & 1.00 & 0.75 & 0.29 & 0.29 & 0.17 & 0.08 & 0.42 & 0.26 & 0.09 \\
\hline & Se & 1.01 & 0.76 & 0.29 & 0.41 & 0.19 & 0.15 & 0.52 & 0.32 & 0.15 \\
\hline \multirow{5}{*}{6} & Fixed & 1.19 & 1.00 & 0.37 & 0.32 & 0.23 & 0.08 & 0.59 & 0.37 & 0.14 \\
\hline & $\mathrm{Sb}$ & 1.37 & 1.05 & 0.41 & 0.34 & 0.24 & 0.08 & 0.60 & 0.37 & 0.14 \\
\hline & Sc & 1.37 & 1.05 & 0.41 & 0.37 & 0.24 & 0.08 & 0.62 & 0.38 & 0.15 \\
\hline & $\mathrm{Sd}$ & 1.37 & 1.05 & 0.41 & 0.47 & 0.25 & 0.09 & 0.68 & 0.42 & 0.16 \\
\hline & $\mathrm{Se}$ & 1.39 & 1.05 & 0.41 & 0.64 & 0.26 & 0.15 & 0.80 & 0.51 & 0.17 \\
\hline \multirow{5}{*}{8} & Fixed & 1.50 & 1.25 & 0.48 & 0.45 & 0.27 & 0.10 & 0.81 & 0.52 & 0.20 \\
\hline & $\mathrm{Sb}$ & 1.72 & 1.32 & 0.53 & 0.48 & 0.27 & 0.11 & 0.83 & 0.53 & 0.20 \\
\hline & $\mathrm{Sc}$ & 1.72 & 1.32 & 0.53 & 0.53 & 0.28 & 0.11 & 0.86 & 0.54 & 0.21 \\
\hline & $\mathrm{Sd}$ & 1.73 & 1.32 & 0.53 & 0.67 & 0.28 & 0.12 & 0.94 & 0.60 & 0.22 \\
\hline & $\mathrm{Se}$ & 1.75 & 1.33 & 0.54 & 0.90 & 0.29 & 0.16 & 1.11 & 0.71 & 0.24 \\
\hline \multirow{5}{*}{12} & Fixed & 2.19 & 1.77 & 0.68 & 0.84 & 0.40 & 0.18 & 1.36 & 0.90 & 0.35 \\
\hline & $\mathrm{Sb}$ & 2.51 & 1.90 & 0.77 & 0.87 & 0.41 & 0.19 & 1.38 & 0.91 & 0.36 \\
\hline & $\mathrm{Sc}$ & 2.52 & 1.90 & 0.77 & 0.95 & 0.41 & 0.20 & 1.42 & 0.93 & 0.37 \\
\hline & Sd & 2.54 & 1.90 & 0.77 & 1.15 & 0.41 & 0.22 & 1.53 & 0.99 & 0.38 \\
\hline & $\mathrm{Se}$ & 2.59 & 1.91 & 0.77 & 1.49 & 0.43 & 0.24 & 1.78 & 1.13 & 0.41 \\
\hline \multirow{5}{*}{16} & Fixed & 3.00 & 2.28 & 0.89 & 1.28 & 0.50 & 0.27 & 1.98 & 1.31 & 0.52 \\
\hline & $\mathrm{Sb}$ & 3.51 & 2.50 & 1.01 & 1.34 & 0.52 & 0.28 & 2.02 & 1.32 & 0.53 \\
\hline & $\mathrm{Sc}$ & 3.52 & 2.50 & 1.01 & 1.46 & 0.52 & 0.30 & 2.07 & 1.35 & 0.54 \\
\hline & Sd & 3.55 & 2.50 & 1.02 & 1.76 & 0.53 & 0.33 & 2.25 & 1.44 & 0.56 \\
\hline & Se & 3.66 & 2.51 & 1.02 & 2.25 & 0.54 & 0.35 & 2.64 & 1.63 & 0.60 \\
\hline
\end{tabular}

mode of the buildings with and without shear wall for a fixed base condition.

The value of natural period of buildings of varying height over raft foundation with and without incorporation of the soil stiffness is studied and tabulated in Table 5. It is observed that the value of natural period increases with increase in height of the building due to increase in flexibility of building. However, the natural period decreases with the addition of shear wall to the building due to the increase in stiffness of building by addition of shear wall. Natural period is lowest for the building configuration with shear wall at core. Inclusion of soil flexibility in buildings also increases the value of natural period of the building, which is observed to be more in case of soft soil (Se) and less in hard soil (Sb).

Figure 4 exhibits the translation, twisting, and bending that occurs in the building due to vibration. Behaviour of buildings depends on the dynamic characteristics of buildings which are controlled by both their mass and stiffness properties.

Buildings can vibrate in different mode shapes depending on the number of dynamic degrees of freedom in the building. The response of the building is mainly governed by the first few mode shapes depending on the building type. In short buildings, the first vibration mode may be the only governing mode with more than $90-95 \%$ participation factor. However, with increasing number of storeys, flexibility of buildings increases bringing higher mode effects into the picture. Therefore, for taller buildings, even with regular symmetric plan, first mode may not be the only governing mode; participation from higher modes may also be significant.

The contribution of first mode is highest among all possible mode shapes in regular buildings along each principal axis, while the contribution of higher modes reduces depending on the natural characteristics of buildings. Every mode imposes some force demand on buildings. Adding the forces imposed by all the modes gives the total force on the building.

The basic assumption of equivalent static method is that only the first mode of vibration of buildings governs the dynamics and the effects of higher modes which are not significant; therefore, higher modes are not considered in the analysis. In addition it is also noted that the natural period of the 3D finite element model of the building with fixed base is comparably higher than the natural period obtained by approximate period formulae suggested in codes, considering the height of the building as a single parameter. The natural 

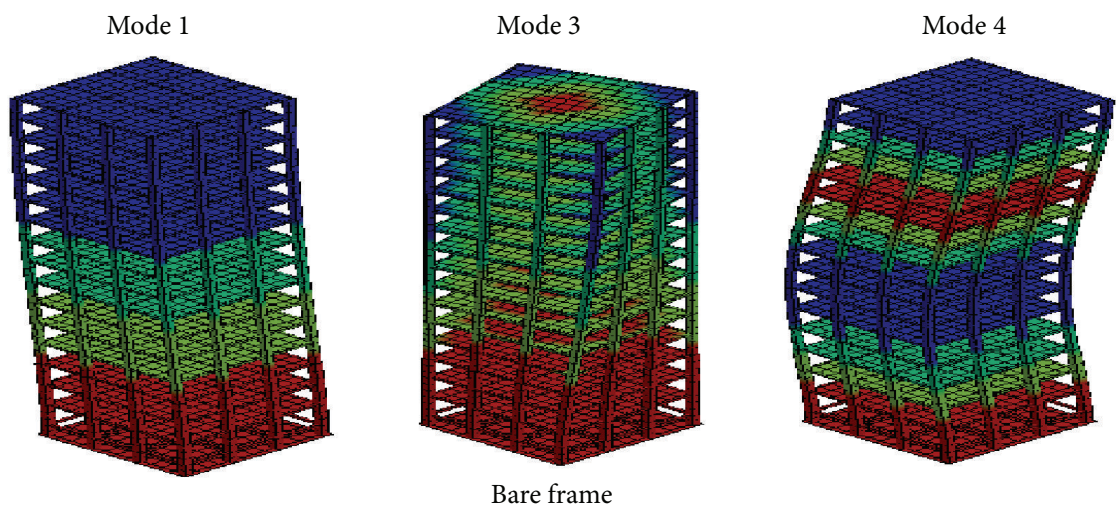

(a)
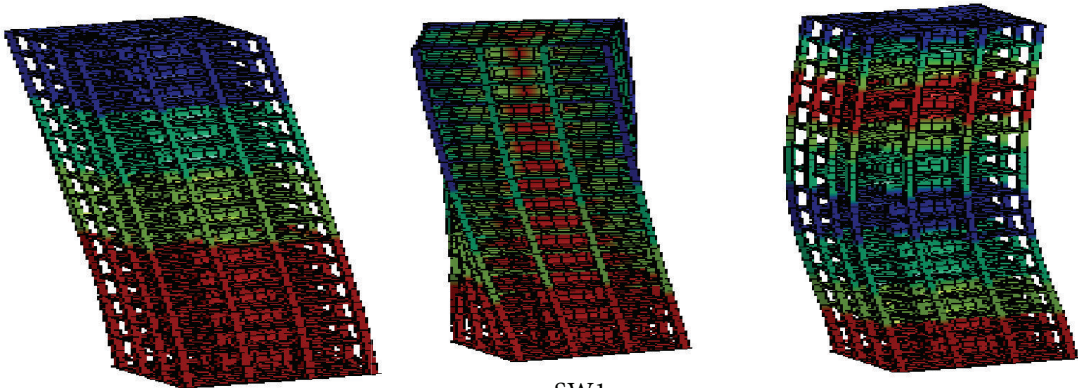

SW1

(b)
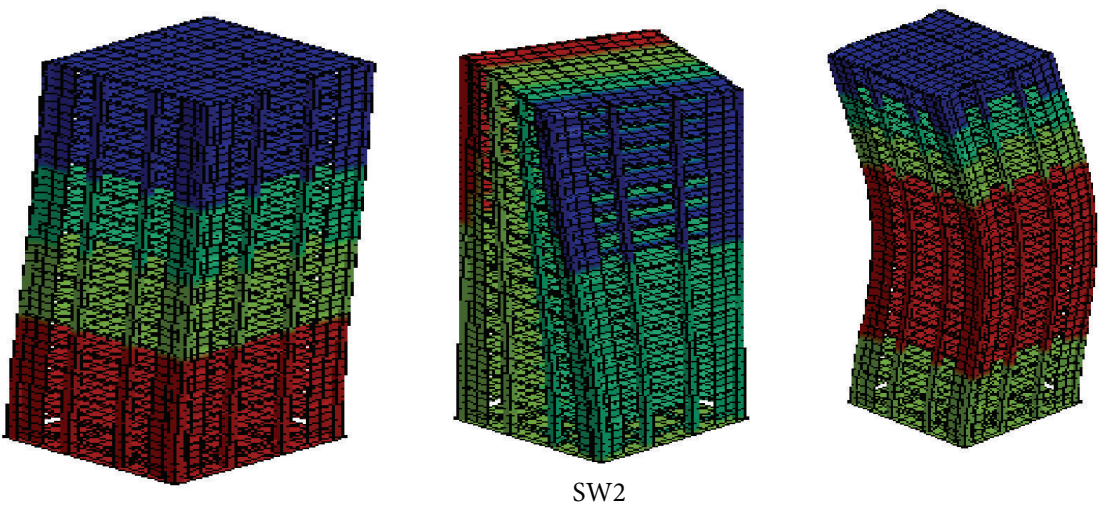

(c)

FIGURE 4: 1st, 3rd, and 4th mode shapes of 16-storey building: (a) bare frame, (b) SW1, and (c) SW2.

period obtained from 3D finite element analysis is closer to reality since it considers the mass, in plane, and out of plane stiffness contribution from all structural elements.

4.2. Spectral Acceleration Coefficient. Spectral acceleration coefficient is the vital component of design base shear estimation based on design response spectrum and is dependent on the primary parameter, the fundamental period $T$ of the building. Spectral acceleration coefficient for a structure is defined as the maximum acceleration of an equivalent single degree of freedom structure with same natural period subjected to design basis earthquake excitations for the region. As the period varies due to the effect of building interaction with supporting soil, the value of spectral acceleration coefficient is liable to shift to high or low values which in turn affect the value of design base shear calculated.

Spectral acceleration coefficient value of structures founded on various soil types was obtained from the design response spectrum, as suggested in IS and EC8 codes. It is found that the value of spectral acceleration coefficient obtained by considering the three dimensional soil-structure interaction effect (SSI) in buildings is much less than those obtained by the standard conventional design practice (fixed). Among the building configurations considered spectral acceleration is found to be least for multistorey moment 


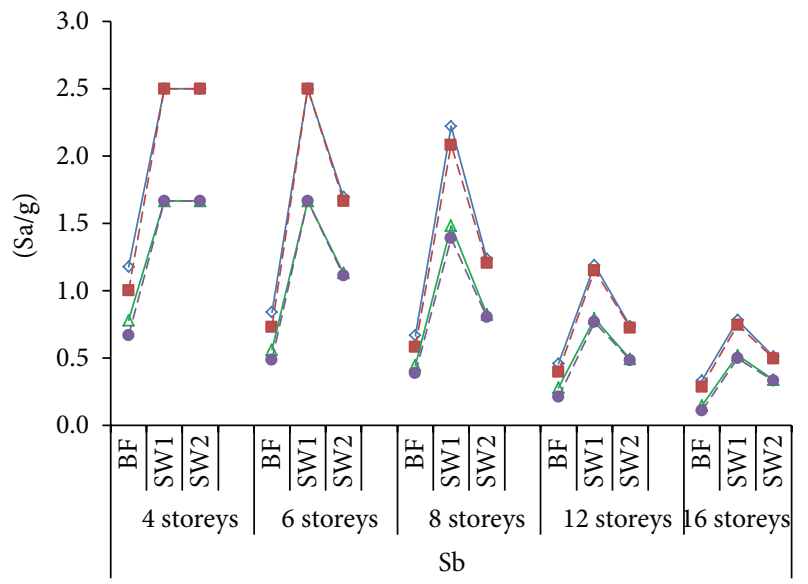

(a)

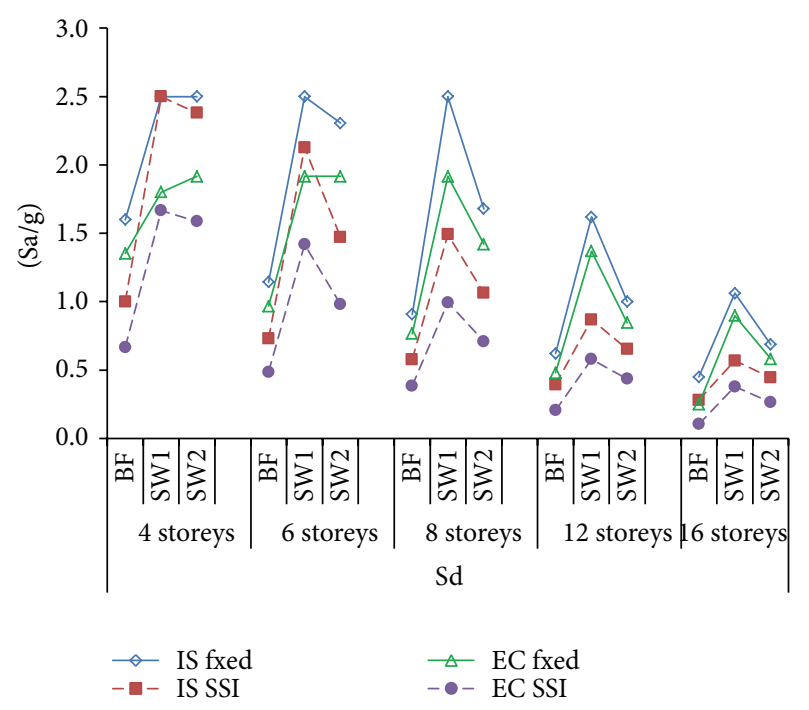

(c)

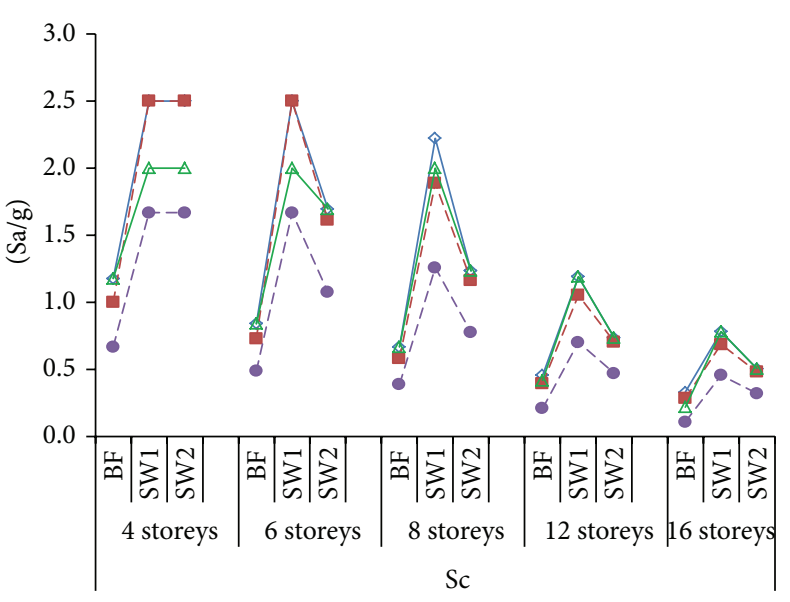

(b)

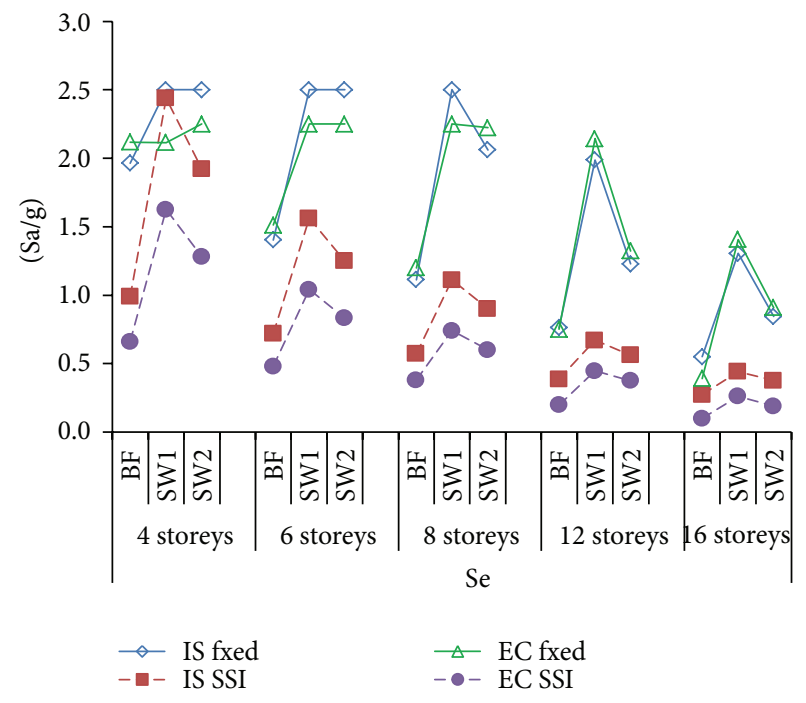

(d)

FIGURE 5: Value of spectral acceleration coefficient as per IS 1893 and EC8 for various site classes.

resisting bare frames and highest for buildings with shear wall at core, with or without SSI effect. This is due to the reduction in fundamental natural period of buildings by the addition of shear walls.

The values of spectral acceleration coefficient obtained for buildings with fixed base assumed to be constructed over different soil sites (fixed) and incorporating actual soilstructure interaction effect (SSI) are as shown in Figure 5 for various site classes.

It is observed from Figure 5 that the value of design spectral acceleration obtained as per IS code is higher than EC code. The variation in the value of spectral acceleration coefficient obtained from fixed base condition and 3D integrated building-foundation-soil system (SSI) is more prominent in case of soft and stiff soil when compared with dense soil and rock. The lowest value of spectral acceleration coefficient is observed for 16-storey moment resisting bare frame building to be irrespective of the soil type considered as the natural period corresponds to the descending curve of design response spectrum. The highest values are observed in buildings of fixed base with shear wall at the core regardless of the code considered.

In case of 4-storey building the value of spectral acceleration coefficient as per EC code for fixed base condition is highest for buildings with shear walls at all four corners of the exterior frames (SW2) in stiff (Sd) and soft (Se) soil types.

4.3. Design Base Shear. Seismic lateral vulnerability of the structure is reflected by the seismic base shear and is regarded as one of the primary inputs in seismic design. Base shear of the buildings is obtained from the expressions given in codes for design spectra of $5 \%$ critical damping. The values of base shear for multistorey reinforced concrete framed buildings of different heights with and without shear wall supported on raft foundation over Sb, Sc, Sd, and Se soil site as per IS 1893 and EC 8 codes are as shown in Figure 6.

Regardless of the codes considered the base shear obtained by considering the three dimensional soil-structure 


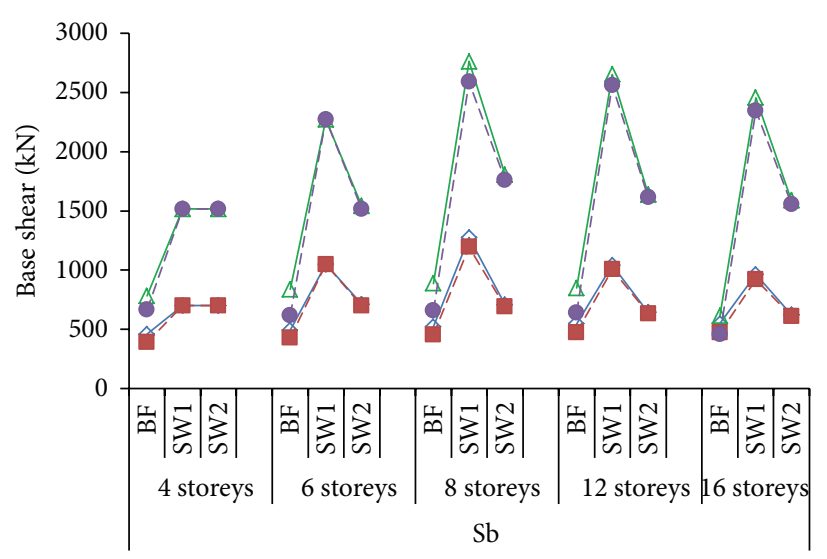

(a)

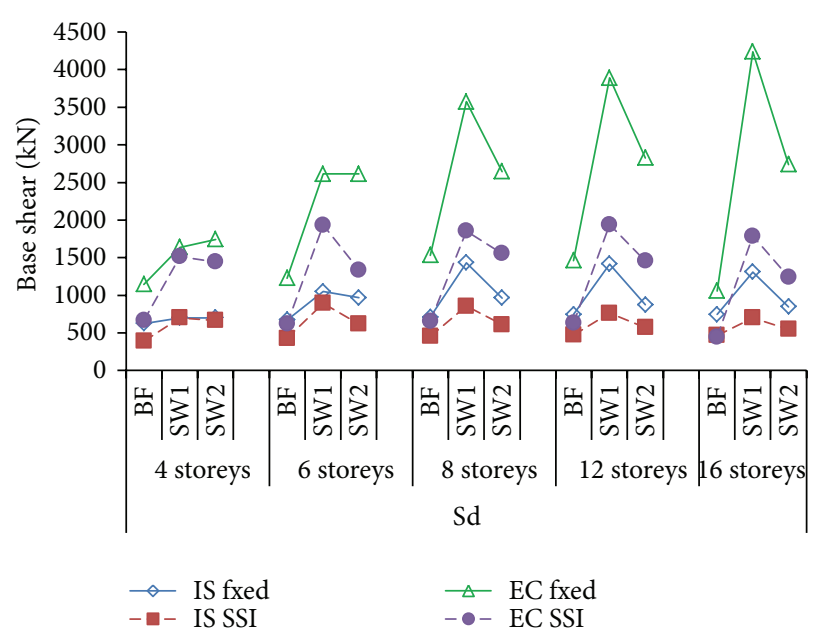

(c)

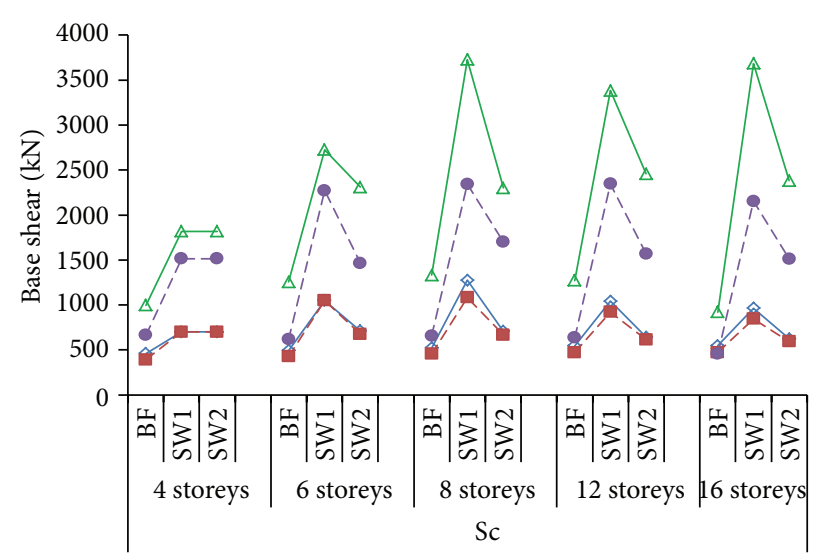

(b)

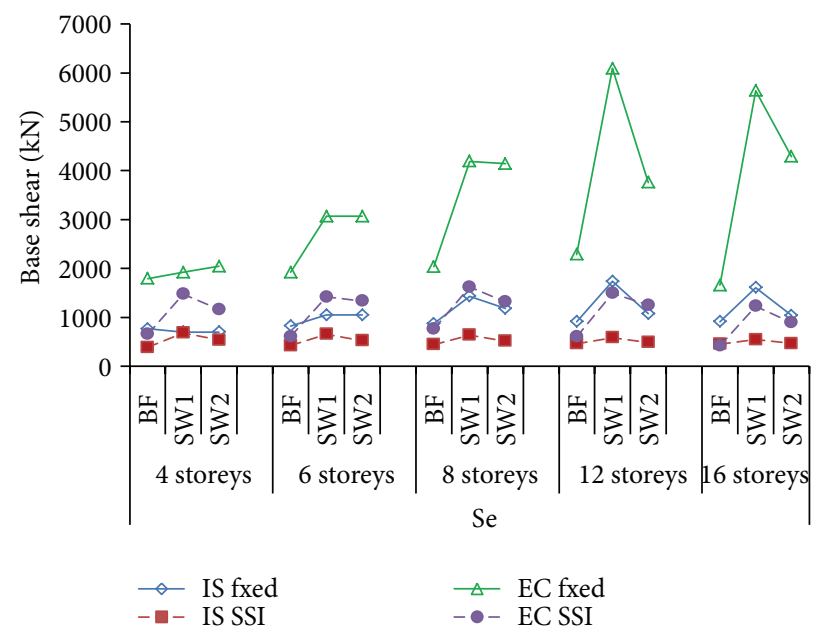

(d)

FIGURE 6: Value of base shear as per IS 1893 and EC8 for various site classes.

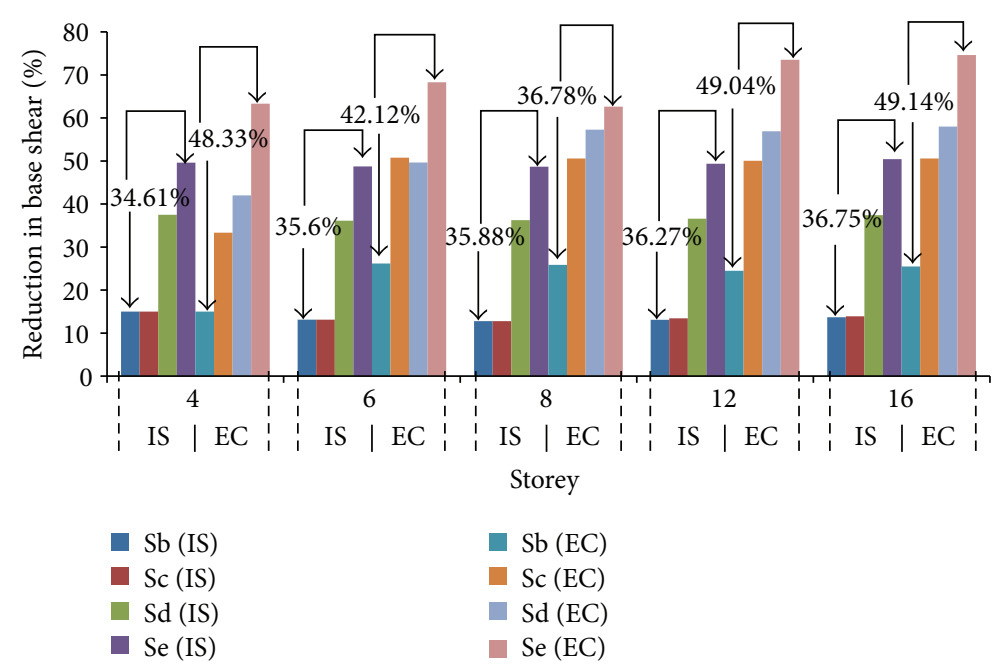

FIGURE 7: Percentage reduction in base shear value of bare frame building over varying soil types. 

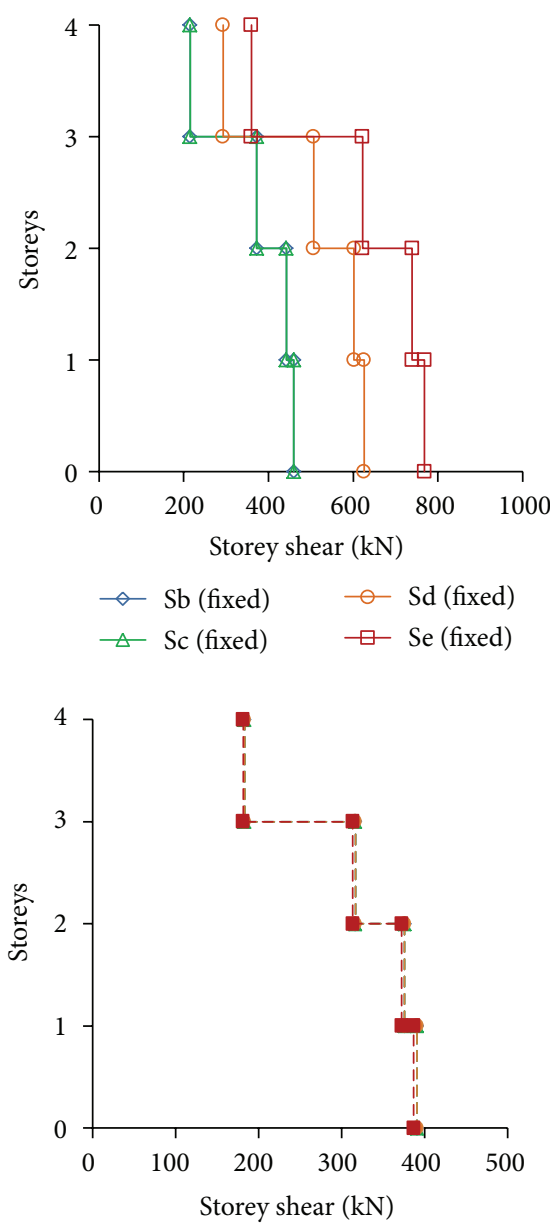

- - Sb (SSI)

$-\mathrm{Sc}$ (SSI)

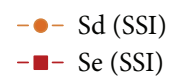

Bare frame

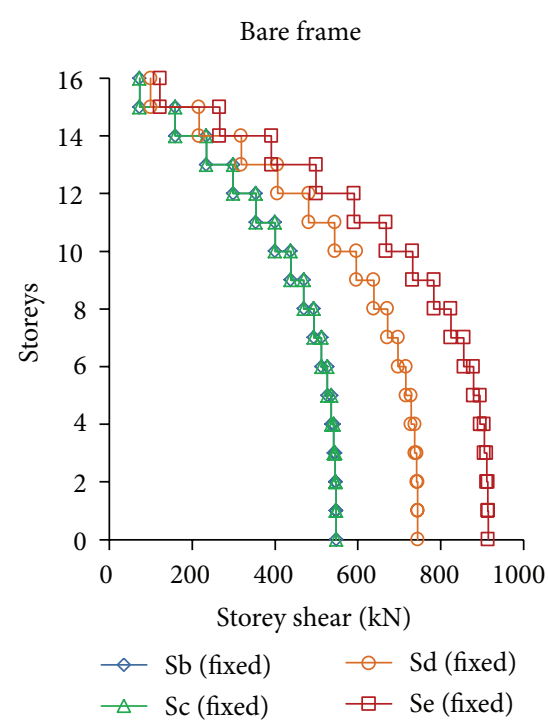

$\begin{array}{ll}\neg \mathrm{Sb} \text { (fixed) } & -\mathrm{Sd} \text { (fixed) } \\ \triangle \mathrm{Sc} \text { (fixed) } & \square \mathrm{Se} \text { (fixed) }\end{array}$
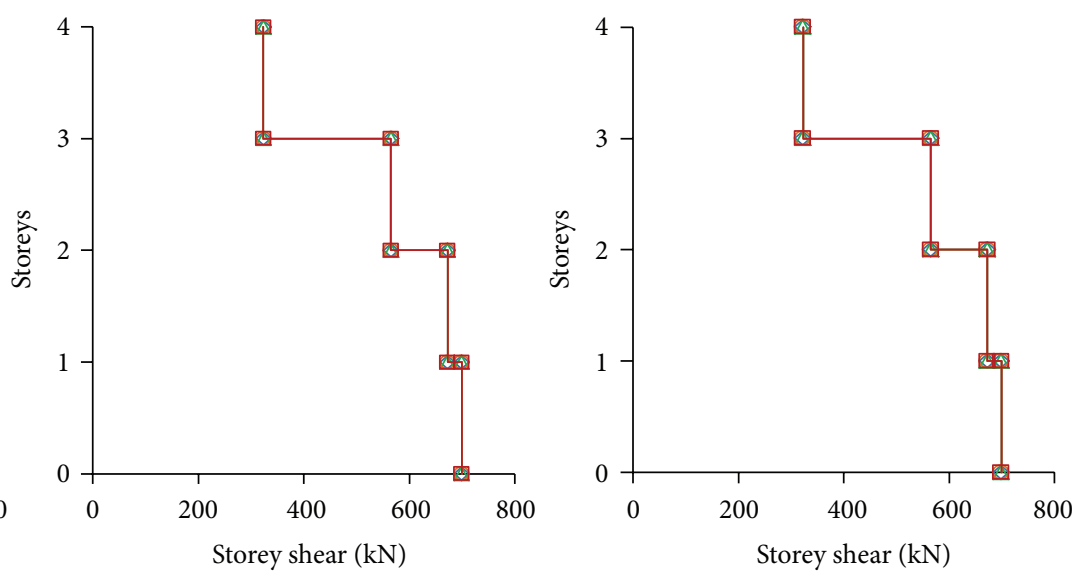

$\begin{array}{ll}\neg \mathrm{Sb} \text { (fixed) } & -\mathrm{Sd} \text { (fixed) } \\ \triangle \mathrm{Sc} \text { (fixed) } & \square \mathrm{Se} \text { (fixed) }\end{array}$

$\multimap \mathrm{Sb}$ (fixed)
$\rightarrow \mathrm{Sc}$ (fixed)
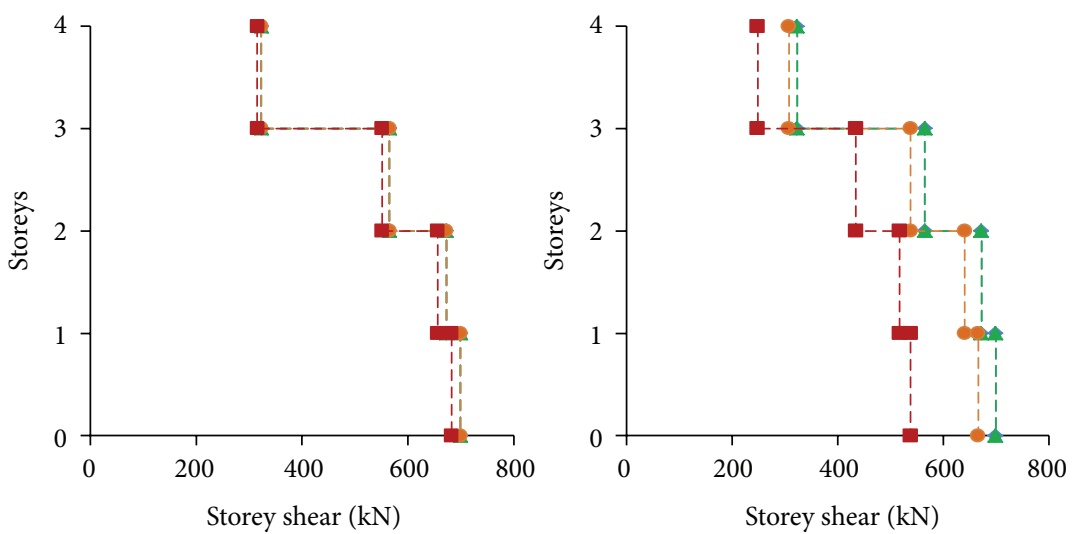

- Sb (SSI)

$-\bullet-\mathrm{Sd}(\mathrm{SSI})$

- Sb (SSI)

$-\bullet-\operatorname{Sd}(\mathrm{SSI})$

$-\mathrm{Sc}(\mathrm{SSI})$

$-\square-\operatorname{Se}(\mathrm{SSI})$
- - Se (SSI)

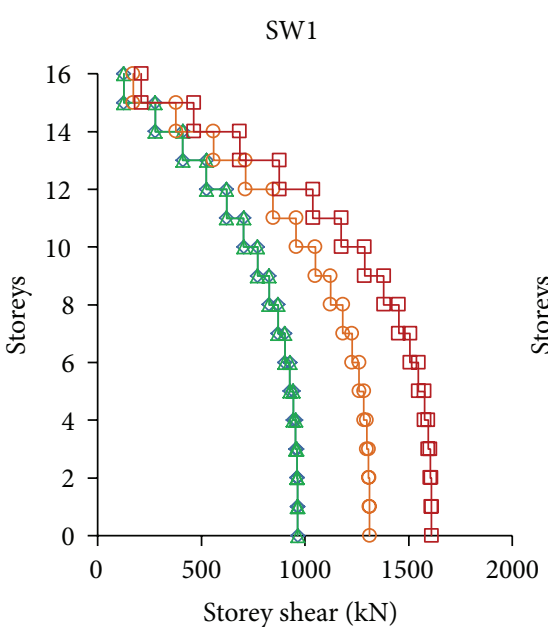

$\begin{array}{ll}\neg \mathrm{Sb} \text { (fixed) } & -\mathrm{Sd} \text { (fixed) } \\ \triangle \mathrm{Sc} \text { (fixed) } & \square \mathrm{Se} \text { (fixed) }\end{array}$

Figure 8: Continued.
SW2

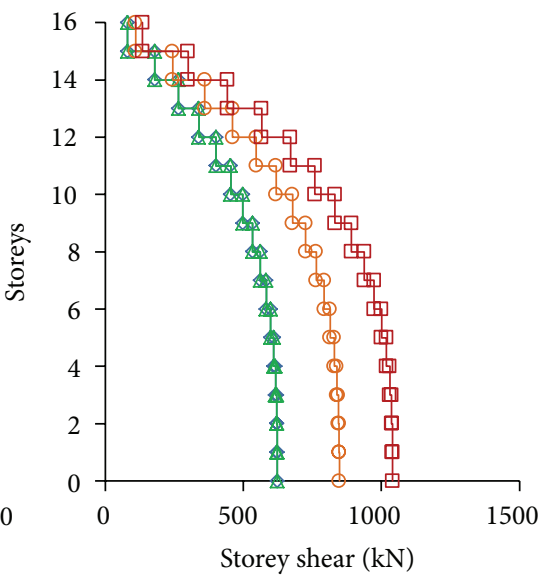

$\neg \mathrm{Sb}$ (fixed) $\quad-\mathrm{Sd}$ (fixed)

$\triangle \mathrm{Sc}$ (fixed) $\quad \square \mathrm{Se}$ (fixed) 

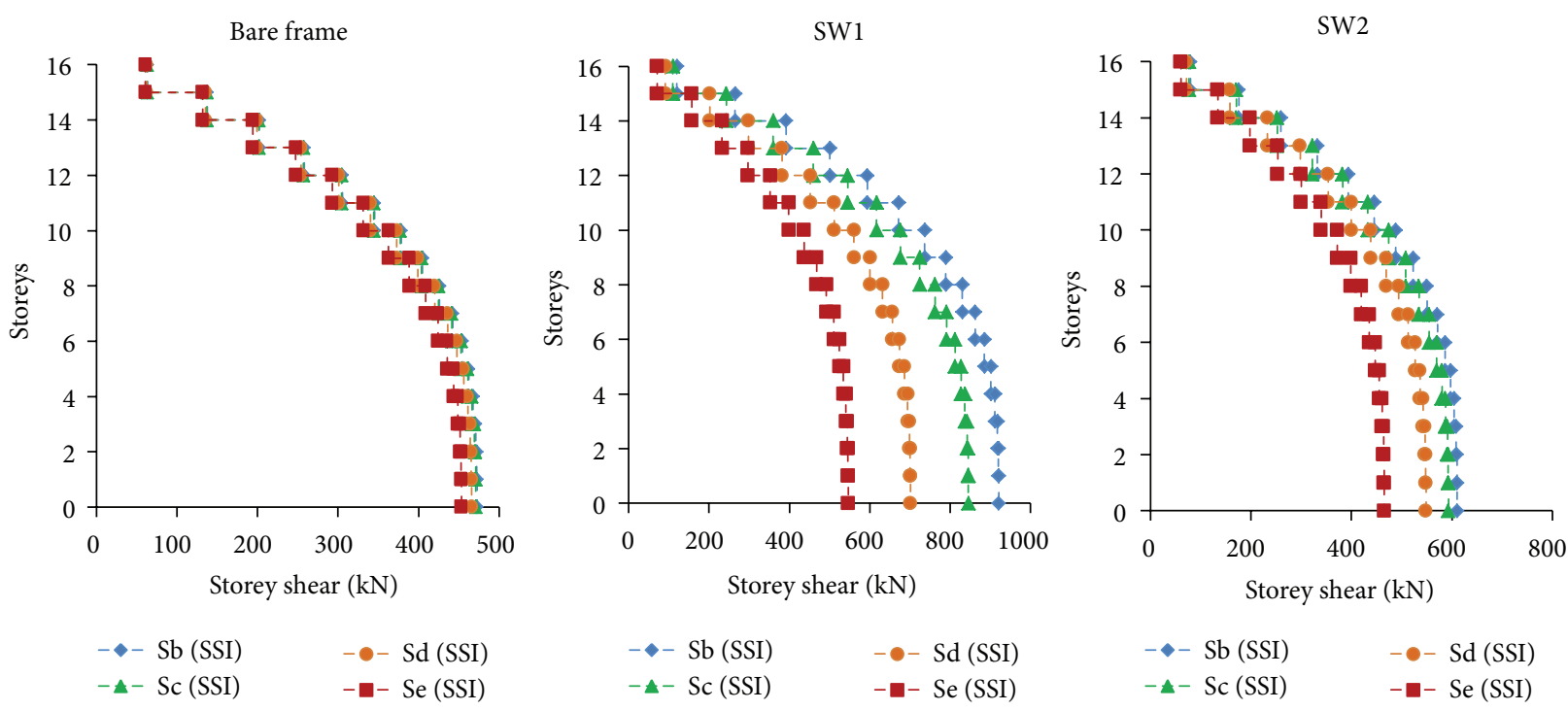

FIGURE 8: Variation of storey shear in 4-storey and 16-storey buildings as per IS code.

interaction effect (SSI) in buildings is much less than those obtained by the standard conventional design practice (Fixed). The value of base shear with or without SSI effect is found to be least in multistorey moment resisting bare frames and highest for building configurations with shear wall at core. This is due to addition of mass and drastic reduction in fundamental natural period by the addition of shear walls which increases the spectral acceleration coefficient of shear wall buildings more than bare frame.

It is observed that SSI effect is negligible in the case of buildings founded in soil type Sb but it increases with increase in flexibility of soil. As per IS code values, the interaction effect is less than $15 \%$ if the structure is founded on soil types $\mathrm{Sb}$ and $\mathrm{Sc}$ and less than $66 \%$ on soil types Se. However, as per EC8 code it is less than $26 \%$ in soil type Sb and $79 \%$ in soil type Se.

The values of base shear in buildings of all heights with or without SSI effect according to EC8 seismic code provisions are higher than that with IS provisions.

Figure 7 shows the percentage reduction in base shear value of bare frame building over varying soil types when compared with fixed base condition. The base shear values obtained are very different for different ground types and building heights. As the number of storeys increases, the mass of the structure also increases; hence, the base shears obtained become larger. When the effect of SSI (3D integrated building-foundation-soil system) is observed it is seen that as flexibility of soil increases the value of base shear decreases, since base shear is dependent on the primary factor, natural period $(T)$. With the increase in flexibility of soil, the natural period of the building increases and base shear decreases due to the lower value of spectral acceleration coefficient obtained which corresponds to the descending curve of design response spectrum. However, the values of base shear obtained as per conventional method for buildings of varying height with fixed base assumed to be constructed over different soil sites show increase in the value of base shear with increasing flexibility of soil.

4.4. Storey Shear. Storey shear is the sum of design lateral forces at all levels above the storey under consideration. Storey shear force in shear wall buildings are generally carried by horizontal shear in the wall and interface between the wall and beams. Storey shear value as per IS and EC8 seismic codes are calculated and plotted for buildings with different heights resting on different soil types.

Representative variations in the pattern of distribution of lateral shear force in 4- and 16-storey buildings corresponding to the seismic provisions of IS and EC8 codes are as shown in Figures 8 and 9. It is observed that the value of storey shear increases with decrease in stiffness of soil and so forth; it is highest for the soft soil type (Se) and lowest for hard soil type (Sb).

For all the building types considered the value of storey shear obtained as per EC code is higher than that according to IS code provisions.

\section{Conclusions}

The present study attempts to analyse multistorey reinforced concrete building frames with shear wall placed at core and all four corners of the exterior frames of building considering the flexibility of supporting soil. The results of the study lead to the following conclusions.

(1) Fundamental natural periods of the soil-structure system are more than the corresponding values of the same building with fixed-base. It increases with increase in flexibility of soil and increase in height of the building and decreases with the addition of shear wall. 


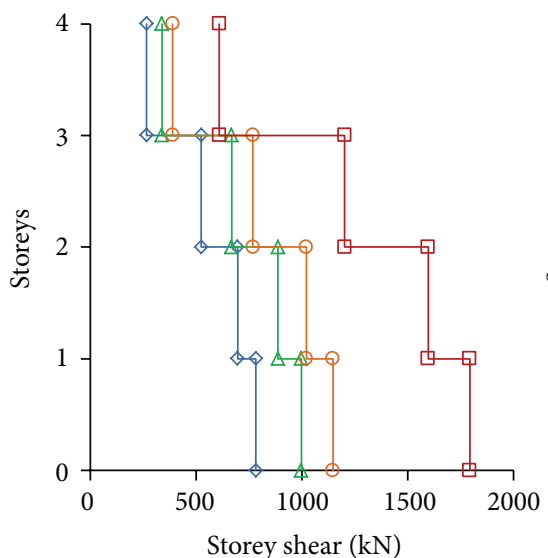

$\neg \mathrm{Sb}$ (fixed) $\quad-\quad \mathrm{Sd}$ (fixed)

$\triangle \mathrm{Sc}$ (fixed) $\quad \square \mathrm{Se}$ (fixed)

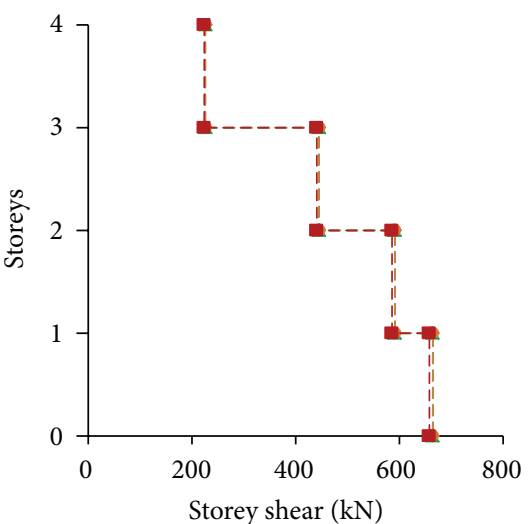

- Sb (SSI)

- - Sc (SSI)

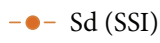

- - Se (SSI)

Bare frame

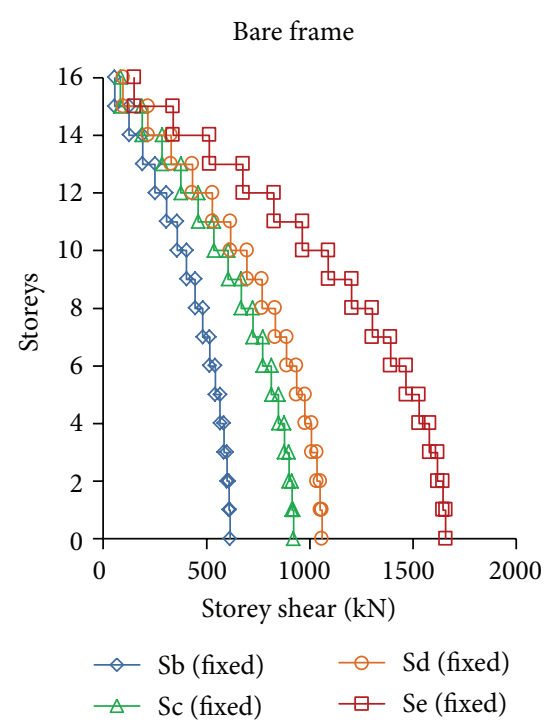

$$
\begin{array}{ll}
\neg \mathrm{Sb} \text { (fixed) } & -\mathrm{Sd} \text { (fixed) } \\
\triangle \mathrm{Sc} \text { (fixed) } & \square \mathrm{Se} \text { (fixed) }
\end{array}
$$
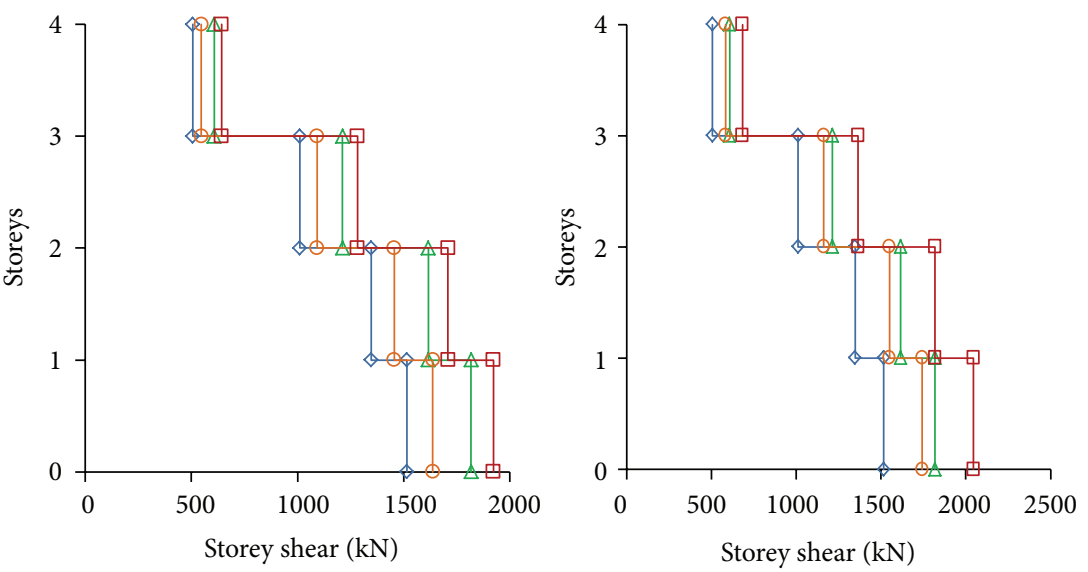

$$
\begin{array}{ll}
\neg \mathrm{Sb} \text { (fixed) } & -\mathrm{Sd} \text { (fixed) } \\
\triangle \mathrm{Sc} \text { (fixed) } & \square \mathrm{Se} \text { (fixed) }
\end{array}
$$$$
\rightarrow \mathrm{Sb} \text { (fixed) } \quad-\mathrm{Sd} \text { (fixed) }
$$
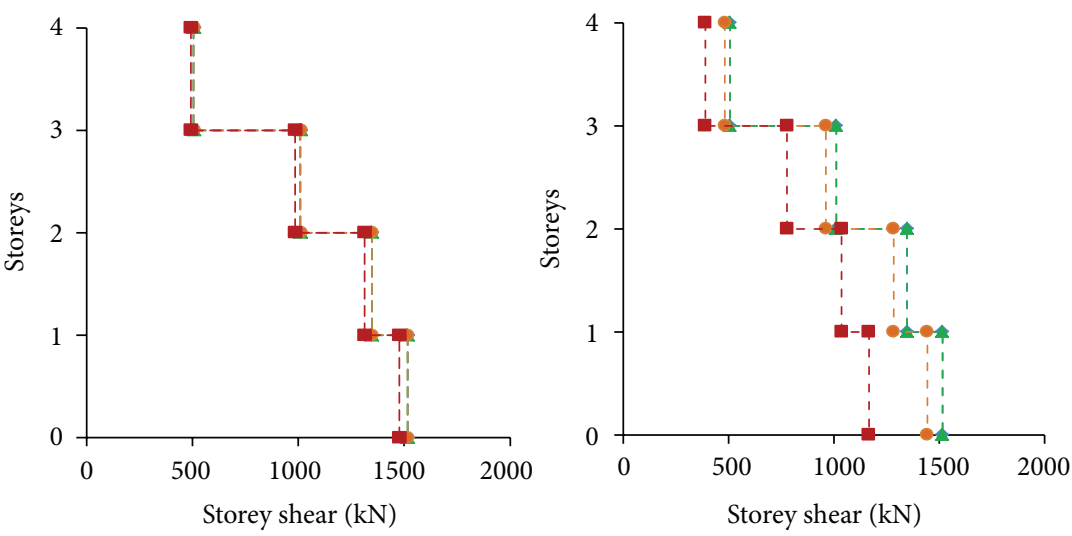

$$
\begin{aligned}
& \text { - } \mathrm{Sb} \text { (SSI) } \\
& -\bullet-\text { Sd (SSI) } \\
& \text {-n- Se (SSI) }
\end{aligned}
$$

$-\mathrm{Sb}(\mathrm{SSI})$

$-\bullet-$ Sd (SSI)

$-\mathrm{Sc}$ (SSI)

$-\square-\operatorname{Se}(\mathrm{SSI})$
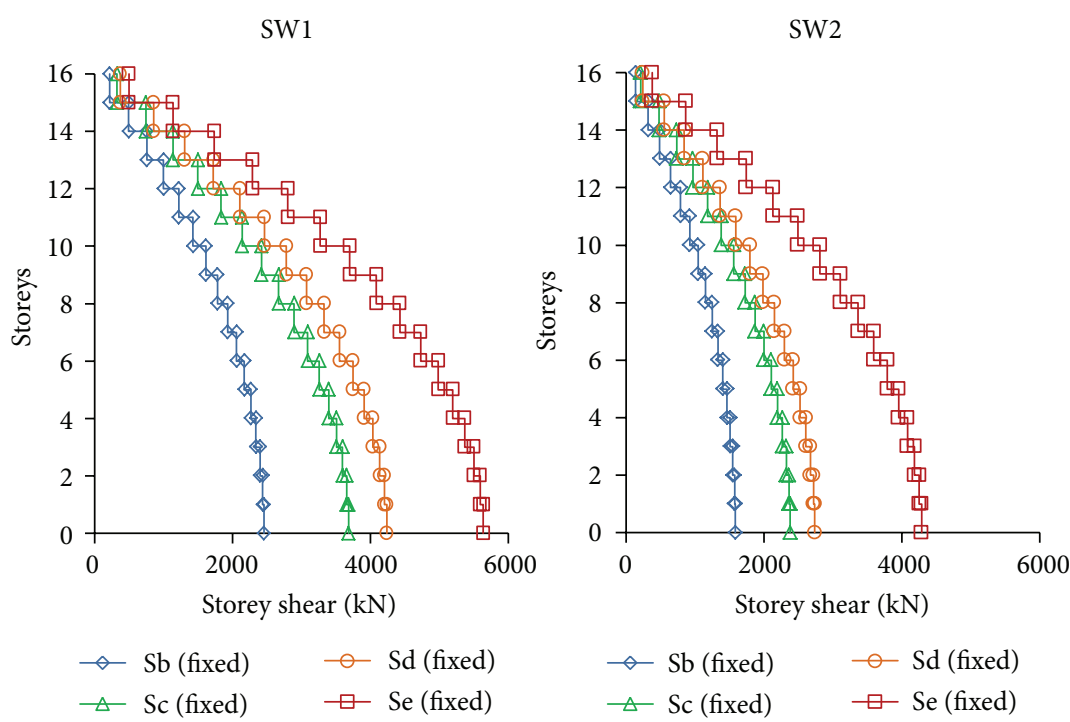

Figure 9: Continued. 

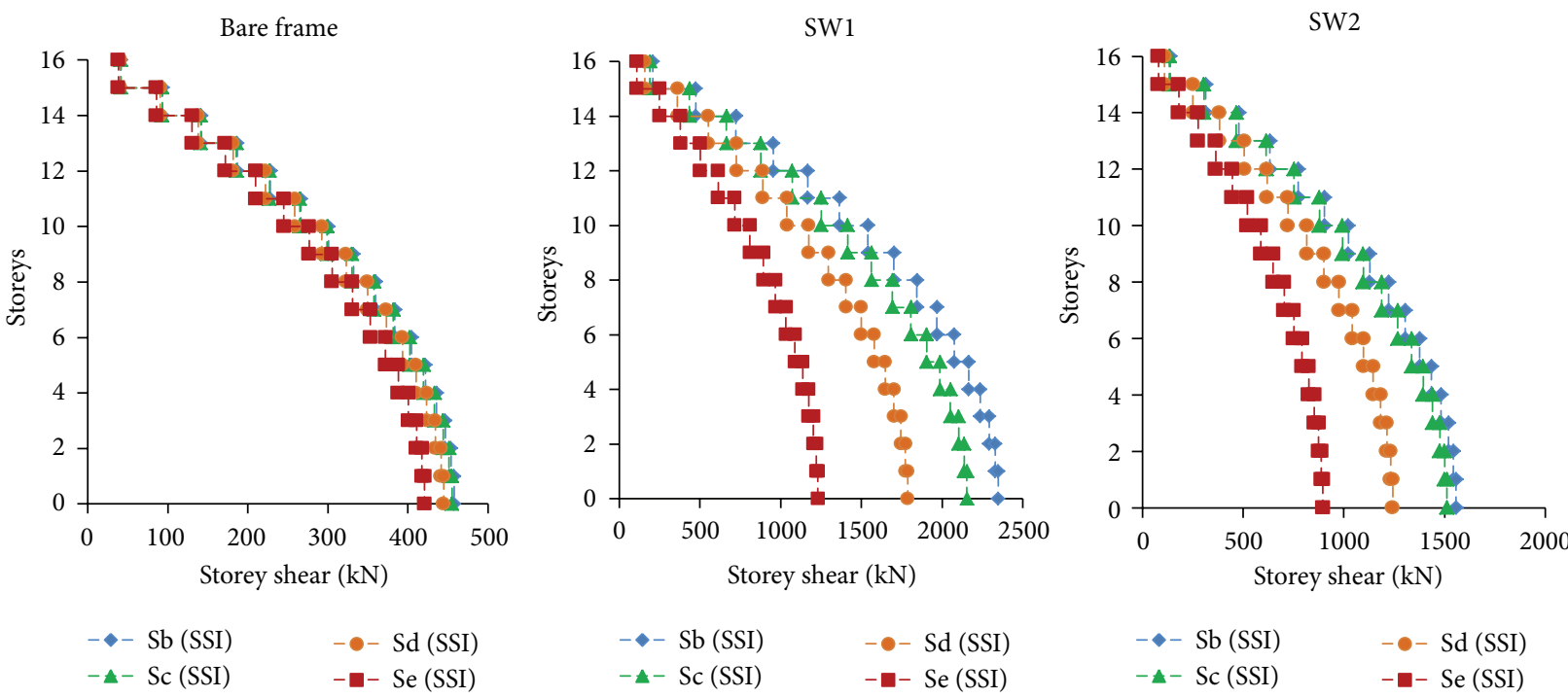

FIGURE 9: Variation of storey shear in 4-storey and 16-storey buildings as per EC code.

(2) Natural period of shear wall buildings is higher for buildings with shear wall placed at all four corners of the exterior frames than those with shear walls at the core.

(3) Spectral acceleration coefficient for buildings with shear wall is higher than that of bare frame buildings. It is highest for buildings with shear wall placed at core.

(4) The values of spectral acceleration coefficients and base shear obtained with actual soil-structure interaction effect are considerably less than the conventional fixed base method.

(5) Base shear increases with increase in flexibility of soil in conventional fixed base method, whereas it decreases with actual soil-structure interaction effect.

(6) Significant differences are observed between the base shear values evaluated using the IS and EC8 codes. EC8 codal provisions give higher value of base shear for buildings than the IS code.

\section{Conflict of Interests}

The authors declare that there is no conflict of interests regarding the publication of this paper.

\section{References}

[1] G. Mylonakis, A. Nikolaou, and G. Gazetas, "Soil-pile-bridge seismic interaction: kinematic and inertial effects. Part I: soft soil," Earthquake Engineering \& Structural Dynamics, vol. 26, no. 3, pp. 337-359, 1997.

[2] R. Roy and S. C. Dutta, "Differential settlement among isolated footings of building frames: the problem, its estimation and possible measures," International Journal of Applied Mechanics and Engineering, vol. 6, pp. 165-186, 2001.
[3] R. Roy and S. C. Dutta, "Effect of soil-structure interaction on dynamic behaviour of building frames on grid foundations," in Proceedings of the Structural Engineering Convention (SEC '01), pp. 694-703, Roorkee, India, 2001.

[4] S. H. R. Tabatabaiefar, B. Fatahi, and B. Samali, "Seismic behavior of building frames considering dynamic soil-structure interaction," International Journal of Geomechanics, vol. 13, no. 4, pp. 409-420, 2013.

[5] J. Bielak, "Dynamic behaviour of structures with embedded foundations," Earthquake Engineering \& Structural Dynamics, vol. 3, no. 3, pp. 259-274, 1975.

[6] J. P. Stewart, G. L. Fenves, and R. B. Seed, "Seismic soilstructure interaction in buildings. I: analytical method," Journal of Geotechnical and Geoenvironmental Engineering, vol. 125, no. 1, pp. 26-37, 1999.

[7] J. P. Stewart, R. B. Seed, and G. L. Fenves, "Seismic soil-structure interaction in buildings. II: empirical findings," Journal of Geotechnical and Geoenvironmental Engineering, vol. 125, no. 1, pp. 38-48, 1999.

[8] K. Bhattacharya and S. C. Dutta, "Assessing lateral period of building frames incorporating soil-flexibility," Journal of Sound and Vibration, vol. 269, no. 3-5, pp. 795-821, 2004.

[9] G. Saad, F. Saddik, and S. Najjar, "Impact of soil-structure interaction on the seismic design of reinforced concrete buildings with underground stories," in Proceedings of the 15th World Conference on Earthquake Engineering, Lisbon, Portugal, 2012.

[10] S. H. R. Tabatabaiefar and A. Massumi, "A simplified method to determine seismic responses of reinforced concrete moment resisting building frames under influence of soil-structure interaction," Soil Dynamics and Earthquake Engineering, vol. 30, no. 11, pp. 1259-1267, 2010.

[11] P. Raychowdhury, "Seismic response of low-rise steel momentresisting frame (SMRF) buildings incorporating nonlinear soilstructure interaction (SSI)," Engineering Structures, vol. 33, no. 3, pp. 958-967, 2011.

[12] R. K. Goel and A. K. Chopra, "Period formulas for momentresisting frame buildings," Journal of Structural Engineering, vol. 123, no. 11, pp. 1454-1461, 1997. 
[13] H. Crowley and R. Pinho, "Period-height relationship for existing European reinforced concrete buildings," Journal of Earthquake Engineering, vol. 8, no. 1, pp. 93-119, 2004.

[14] H. Crowley and R. Pinho, "Simplified equations for estimating the period of vibration of existing buildings," in Proceedings of the 1st European Conference on Earthquake Engineering and Seismology, p. 1122, Geneva, Switzerland, 2006.

[15] C. G. Karayannis, B. A. Izzuddin, and A. S. Elnashai, "Application of adaptive analysis to reinforced concrete frames," Journal of Structural Engineering, vol. 120, no. 10, pp. 2935-2957, 1994.

[16] M. J. Favvata, M. C. Naoum, and C. G. Karayannis, "Limit states of RC structures with first floor irregularities," Structural Engineering and Mechanics, vol. 47, no. 6, pp. 791-818, 2013.

[17] W. Pong, Z. H. Lee, and A. Lee, "A comparative study of seismic provisions between international building code 2003 and uniform building code 1997," Earthquake Engineering and Engineering Vibration, vol. 5, no. 1, pp. 49-60, 2006.

[18] A. Doğangün and R. Livaoğlu, "A comparative study of the design spectra defined by Eurocode 8, UBC, IBC and Turkish Earthquake code on R/C sample buildings," Journal of Seismology, vol. 10, no. 3, pp. 335-351, 2006.

[19] S. K. Ghosh and M. Khuntia, "Impact of seismic design provisions of 2000 IBC: comparison with 1997 UBC," in Proceeding of the 68th Annual Convention-Structural Engineers Association of California (SEAOC '99), pp. 229-254, Santa Barbra, Calif, USA, 1999.

[20] Y. Singh, V. N. Khose, and D. H. Lang, "A comparative study of code provisions for ductile RC frame buildings," in Proceedings of the 15th World Conference on Earthquake Engineering, pp. 2428, Lisbon, Portugal, 2012.

[21] V. N. Khose, Y. Singh, and D. H. Lang, "A comparative study of design base shear for RC buildings in selected seismic design codes," Earthquake Spectra, vol. 28, no. 3, pp. 1047-1070, 2012.

[22] N. Imashi and A. Massumi, "A comparative study of the seismic provisions of Iranian seismic code (standard no. 2800) and international building code 2003," Asian Journal of Civil Engineering: Building and Housing, vol. 12, no. 5, pp. 579-596, 2011.

[23] S. H. C. Santos, L. Zanaica, C. Bucur, S. S. Lima, and A. Arai, "Comparative study of codes for seismic design of structures," Mathematical Modelling in Civil Engineering, vol. 9, no. 1, pp. 112,2013

[24] W. Yayong, "Comparison of seismic actions and structural design requirements in Chinese code GB 50011 and international standard ISO 3010," Earthquake Engineering and Engineering Vibration, vol. 3, no. 1, pp. 1-9, 2004.

[25] T. M. Nahhas, "A comparison of IBC with 1997 UBC for modal response spectrum analysis in standard-occupancy buildings," Earthquake Engineering and Engineering Vibration, vol. 10, no. 1, pp. 99-113, 2011.

[26] W. Pong, G. A. Gannon, and Z. H. Lee, "A comparative study of seismic provisions between the international building code 2003 and Mexico's manual of civil works 1993," Advances in Structural Engineering, vol. 10, no. 2, pp. 153-170, 2007.

[27] S. Malekpour, P. Seyyedi, F. Dashti, and J. F. Asghari, "Seismic performance evaluation of steel moment-resisting frames using Iranian, European and Japanese seismic codes," Procedia Engineering, vol. 14, pp. 3331-3337, 2011.

[28] H. B. Kaushik, D. C. Rai, and S. K. Jain, "A case for use of dynamic analysis in designing for earthquake forces," Current Science, vol. 91, no. 7, pp. 874-877, 2006.
[29] I. Iervolino, G. Maddaloni, and E. Cosenza, "Eurocode 8 compliant real record sets for seismic analysis of structures," Journal of Earthquake Engineering, vol. 12, no. 1, pp. 54-90, 2008.

[30] IS: 1893 (part 1)-2002, Indian Standard Criteria for Earthquake Resistant Design of Structures, Bureau of Indian Standards, New Delhi, India, 2002.

[31] EC 8-2004, Eurocode 8: Design of Structures for Earthquake Resistance Part 1: General Rules, Seismic Actions and Rules for Buildings, European Norm. European Committee for Standardisation, Brussels, Belgium, 2004.

[32] IS: 456-2000, Indian Standard Code of Practice for Plain and Reinforced Concrete, Bureau of Indian Standards, New Delhi, India, 2000.

[33] IS: 13920-1993, Ductile Detailing of Reinforced Concrete Structures Subjected to Seismic Forces-Code of Practice, Bureau of Indian Standards, New Delhi, India, 1993.

[34] D. K. Maharaj, A. Amruthavalli, and K. Nishamathi, "Finite element analysis for frame foundation soil interaction," The Electronic Journal of Geotechnical Engineering, vol. 9C, 2004.

[35] D. Thangaraj and K. Ilamparuthi, "Parametric study on the performance of raft foundation with interaction of frame," The Electronic Journal of Geotechnical Engineering, vol. 15, pp. 861878, 2010.

[36] FEMA 273-1997, NEHRP Guidelines for the Seismic Rehabilitation of Buildings, Federal Emergency Management Agency, Washington, DC, USA, 1997.

[37] FEMA 356-2000, Prestandard and Commentary for the Seismic Rehabilitation of Buildings, Federal Emergency Management Agency, Washington, DC, USA, 2000. 

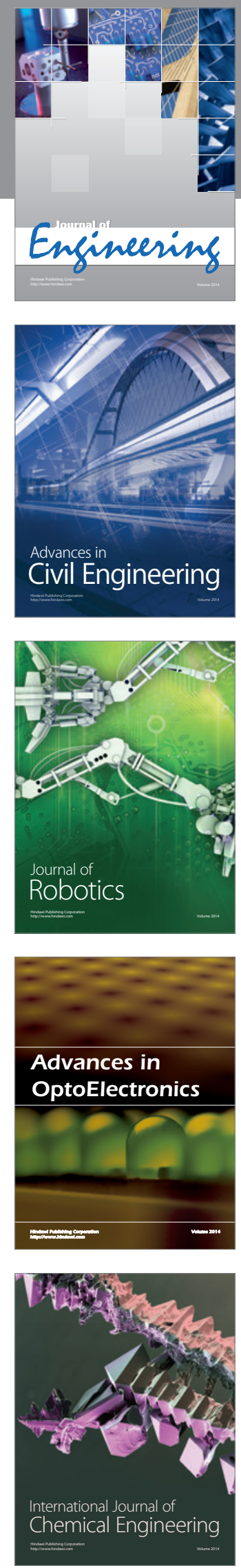

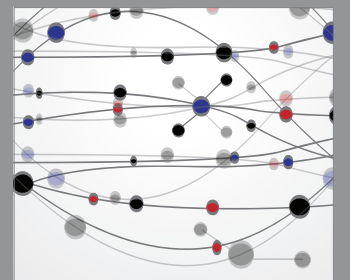

The Scientific World Journal
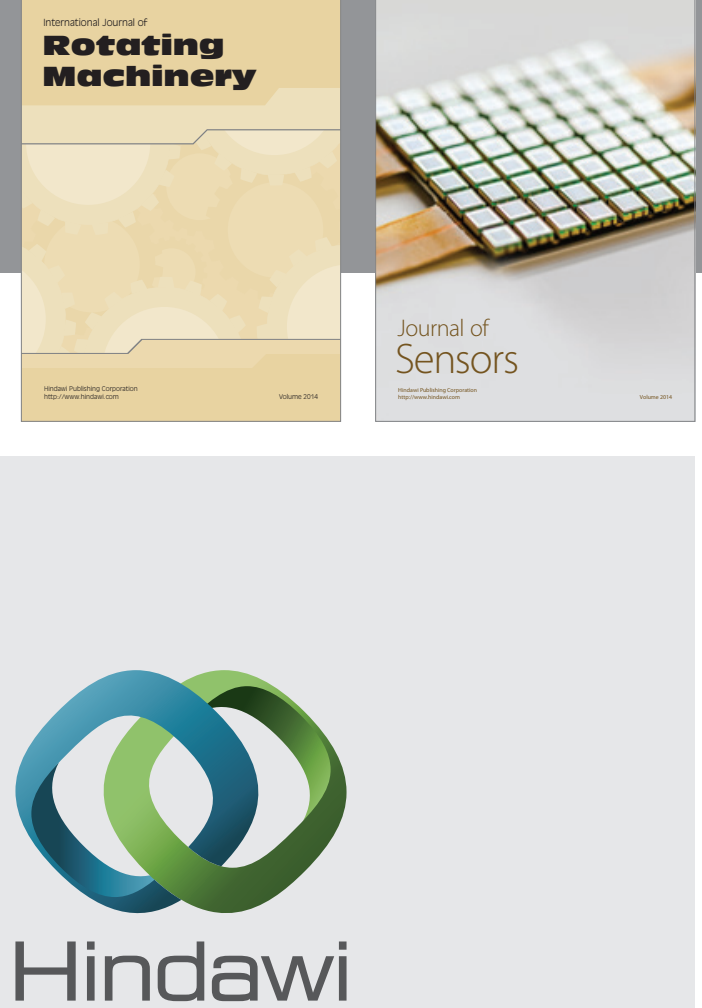

Submit your manuscripts at http://www.hindawi.com
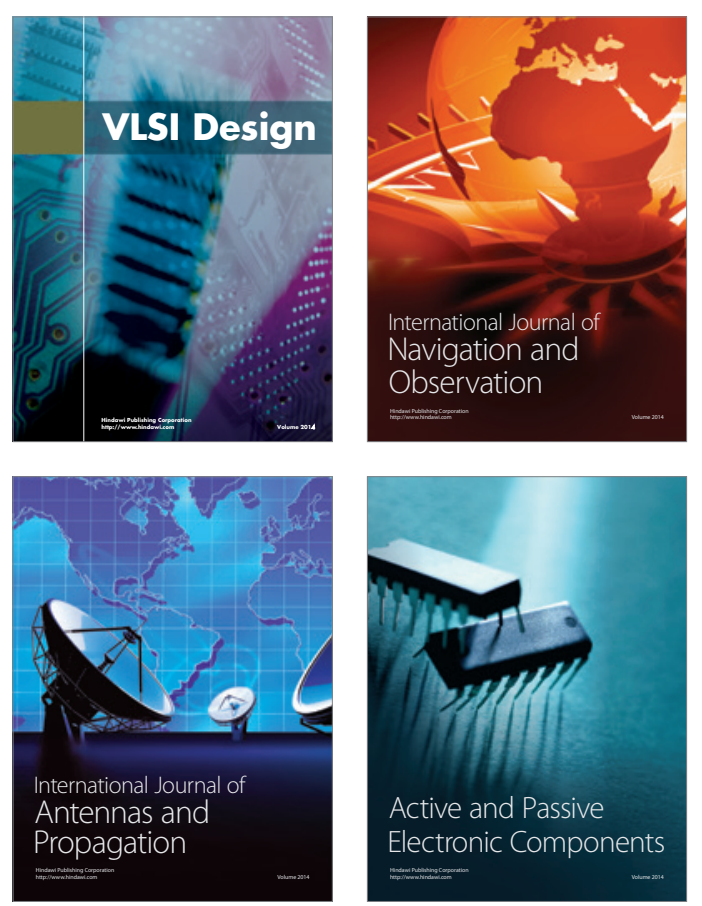
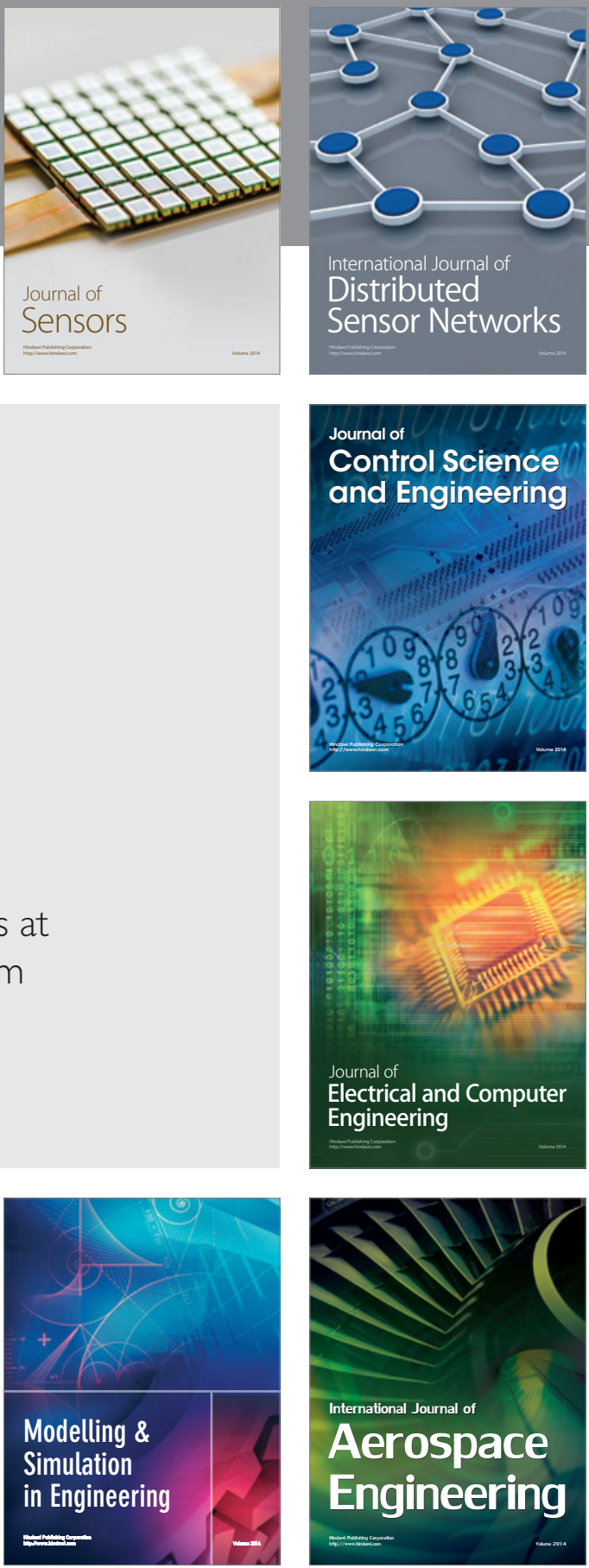

Journal of

Control Science

and Engineering
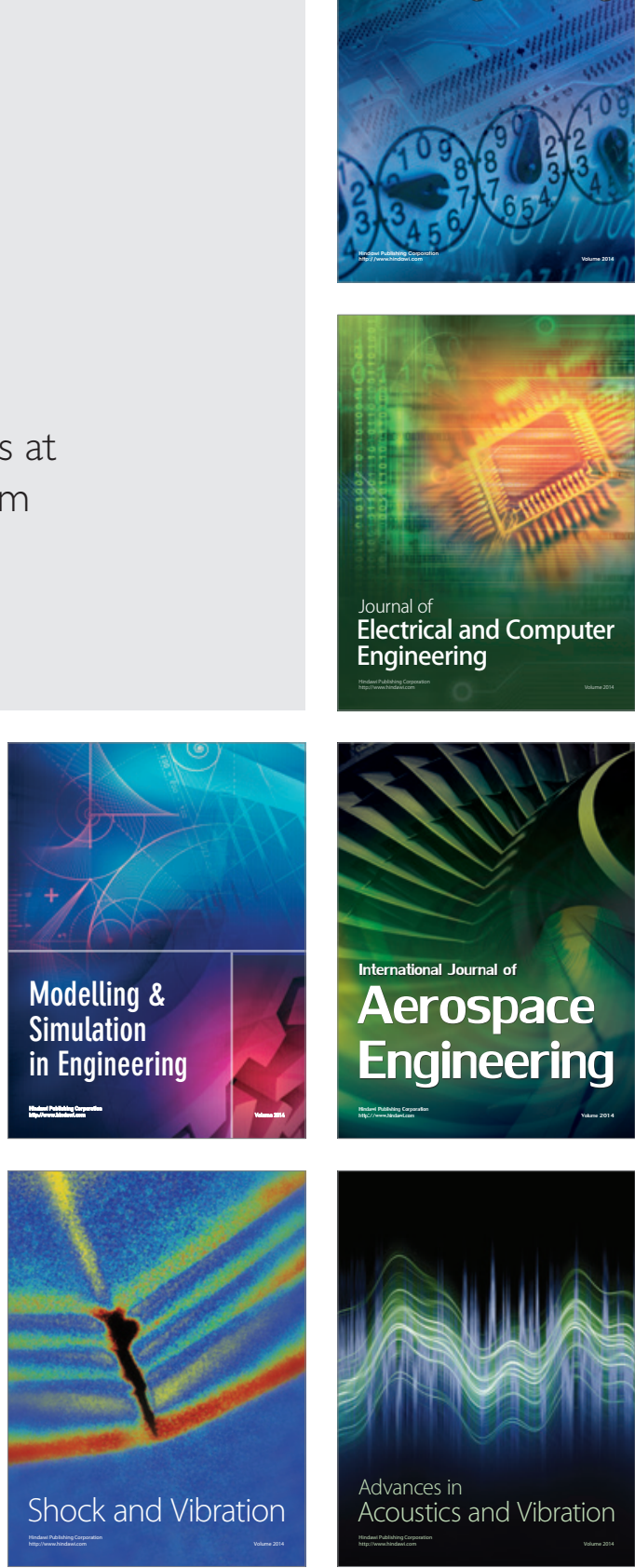